\title{
Is Qualified Immunity Unlawful?
}

\author{
William Baude*
}

The doctrine of qualified immunity operates as an unwritten defense to civil rights lawsuits brought under 42 U.S.C. § 1983. It prevents plaintiffs from recovering damages for violations of their constitutional rights unless a government official violated "clearly established law," which usually requires specific precedent on point. This Article argues that the qualified immunity doctrine is unlawful and inconsistent with conventional principles of statutory interpretation.

Members of the Supreme Court have offered three different justifications for imposing this unwritten defense on the text of Section 1983. First, that the doctrine of qualified immunity derives from a common-law "good-faith" defense. Second, that it compensates for an earlier putative mistake in broadening the statute. Third, that it provides "fair warning" to government officials, akin to the rule of lenity.

On closer examination, each of these justifications falls apart for a mix of historical, conceptual, and doctrinal reasons. There was no such defense; there was no such mistake; lenity ought not apply. Furthermore, even if these things were otherwise, the doctrine of qualified immunity would not be the best response.

DOI: https://dx.doi.org/10.15779/Z38MG7FV8G

Copyright (C) 2018 California Law Review, Inc. California Law Review, Inc. (CLR) is a California nonprofit corporation. CLR and the authors are solely responsible for the content of their publications.

* Neubauer Family Assistant Professor of Law, University of Chicago Law School. I owe thanks to Douglas Gates, Kelly Holt, and Neha Nigam for helpful and dogged research assistance, to the SNR Denton and Alumni Faculty Funds for research support, and to Nathan Chapman, Justin Driver, William Hubbard, Aziz Huq, Marty Lederman, Robert Leider, Richard McAdams, Tejas Narechania, Jennifer Nou, Zach Price, Richard Re, Stephen Sachs, Joanna Schwartz, Fred Smith, and James Stern, as well as to Judge David Barron and other participants in the Sidebar Workshop at the University of Chicago Law School and faculty workshops at the Antonin Scalia Law School at George Mason University and the Chase College of Law at Northern Kentucky University for helpful comments. But my reliance on their help should not insulate me from any liability for my own mistakes. 
The unlawfulness of qualified immunity is of particular importance now. Despite its shoddy foundations, the Supreme Court has been formally and informally reinforcing the doctrine of immunity. In particular, the Court has given qualified immunity a privileged place on its agenda reserved for habeas deference and few other legal doctrines. Rather than doubling down, the Court ought to be beating a retreat.

Introduction 46

I. The Legal Justifications for Qualified Immunity ...................................... 49

A. The Historical Good-Faith Defense ........................................ 51

1. The Court's Account........................................................... 52

2. The Historical Problems ...................................................... 55

a. Legality Instead of Good Faith .................................... 55

b. Not a Freestanding Defense ....................................... 58

c. The Mismatch Problem ..................................................6 60

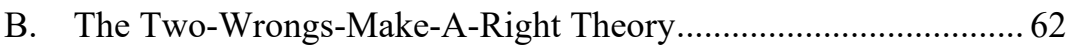

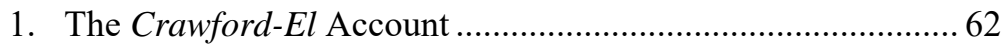

2. The "Under Color of" Problem................................................ 63

3. The Mismatch Problem...................................................... 66

C. The Lenity Theory ….............................................................6 69

1. The Court's Account............................................................69

2. The Civil/Criminal Problem ............................................ 72

3. The Mismatch Problem....................................................... 74

D. What Immunity Can Be Justified? ............................................... 77

1. Justifying Qualified Immunity? ........................................ 77

2. Justifying Other Immunities .............................................. 79

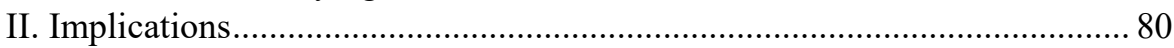

A. Qualified Immunity Doctrine........................................... 80

B. The Qualified Immunity Docket.......................................... 82

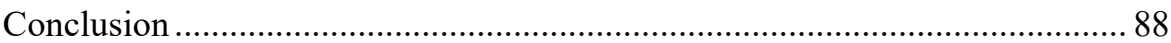

Appendix: Supreme Court Applications of The Qualified Immunity

Standard From 1982 Through 2017 ......................................... 88

\section{INTRODUCTION}

The doctrine of qualified immunity prevents government agents from being held personally liable for constitutional violations unless the violation was of "clearly established law." This doctrine rests on two pillars: its practical consequences and its technical legal justification.

There is a lot of research on the first pillar, the practical consequences of the doctrine. Does it insulate officials too much from liability, leaving them without adequate incentives to respect the constitutional rights of those they 
encounter? ${ }^{1}$ Is it basically redundant in light of the widespread indemnification regimes that prevent officers from having to pay on their own dime $?^{2}$ Does it stall the growth of constitutional doctrine? ${ }^{3}$ Does it instead facilitate the recognition of new constitutional rights? ${ }^{4}$ This research addresses important questions about how qualified immunity does and should work.

But there has been less careful scrutiny of the second pillar-the legal justifications for adopting qualified immunity at all. In part, this may be because the justifications are obscure. But once we dig into the doctrine, we can see that at various times, the Justices have hinted at three major legal justifications for qualified immunity.

This Article takes those legal rationales seriously to see if they hold up and concludes that for the most part, they do not. The modern doctrine of qualified immunity is inconsistent with conventional principles of law applicable to federal statutes - what Stephen Sachs and I have elsewhere called "The Law of Interpretation." While this inquiry may seem narrow, ${ }^{6}$ it is also the first step to reform. Clearing away the legal rationales for qualified immunity lets us see whether there is some other reason that we nonetheless ought to retain the doctrine.

Indeed, one reason that the Court's immunity jurisprudence is so impervious to practical criticism may be a sense that immunity somehow derives from ordinary principles of statutory interpretation, and so it is not the Court's job to change it. That would analogize qualified immunity to the stringent restrictions on habeas relief contained in the Antiterrorism and Effective Death Penalty Act ("AEDPA"), enacted by Congress in 1996. In a series of decisions enforcing AEDPA, the Court has called that statute "a provision of law that some federal judges find too confining, but that all federal judges must obey." The Court takes a similar attitude toward the enforcement of qualified immunity, referring to "the importance of qualified immunity "to

1. Devon W. Carbado, Blue-on-Black Violence: A Provisional Model of Some of the Causes, 104 GEO. L.J. 1479, 1519-24 (2016) (arguing that qualified immunity, among other things, contributes to police violence); see 2 SHELDON H. NAHMOD, CIVIL RIGHTS \& CIVIL LIBERTIES LITIGATION: THE LAW OF SECTION 1983 § 8:5 (4th ed. 2016).

2. See Joanna C. Schwartz, Police Indemnification, 89 N.Y.U. L. REV. 885 (2014).

3. See Aaron L. Nielson \& Christopher J. Walker, The New Qualified Immunity, 89 S. CAL. L. REV. 1 (2015).

4. See John C. Jeffries, Jr., The Right-Remedy Gap in Constitutional Law, 109 YALE L.J. 87, 99-110 (1999); Daryl J. Levinson, Rights Essentialism and Remedial Equilibration, 99 CoLUM. L. REV. 857, 915 (1999).

5. William Baude \& Stephen E. Sachs, The Law of Interpretation, 130 HARV. L. REV. 1079 (2017).

6. But see Richard H. Fallon, Jr., Asking the Right Questions About Officer Immunity, 80 FORDHAM L. REV. 479, 506-07 (2011) ("Critics of official immunity who confine themselves to narrowly textual, historical, and precedential analysis risk missing vitally important questions of constitutional implementation that immunity doctrines inescapably implicate.").

7. White v. Woodall, 134 S. Ct. 1697, 1701 (2014). 
society as a whole." "' But that attitude is justified only if qualified immunity really is required by law. If it is not, if its legal justifications fail, then the decision to keep or change it is the Court's responsibility. ${ }^{9}$ Thus, the investigation of the Court's legal justifications for qualified immunity reinforces, rather than supplants, the many functional challenges to immunity doctrine.

This inquiry is timely-perhaps even urgent. Over the past several decades, the Court has been slowly changing the doctrinal formula for qualified immunity. Most recently, it has begun to strengthen qualified immunity's protection in another way: by giving qualified immunity cases pride of place on the Court's docket. It exercises jurisdiction in cases that would not otherwise satisfy the certiorari criteria and reaches out to summarily reverse lower courts at an unusual pace. Essentially, the Court's agenda is to especially ensure that lower courts do not improperly deny any immunity. This approach sends a strong signal to lower courts and elevates official-protective qualified immunity cases to a level of attention exceeded only by the Court's stateprotective habeas docket.

While the Court doubles down on qualified immunity, the doctrine has also come under increasing outside criticism. Recently publicized episodes of police misconduct vividly illustrate the costs of unaccountability. Indeed, the NAACP Legal Defense Fund has explicitly called for "re-examining the legal standards governing ... qualified immunity." 10 The legal director of the ACLU of Massachusetts has named the doctrine of qualified immunity as among the policing precedents that "we must seek to tear down." 11 Judge Jon Newman has argued that "the defense of qualified immunity should be abolished" by Congress. ${ }^{12}$ These calls make it all the more important to figure out whether the modern doctrine of qualified immunity has a legal basis in the first place.

8. San Francisco v. Sheehan, 135 S. Ct. 1765, 1774 n.3 (2015) (quoting Harlow v. Fitzgerald, 457 U.S. 800, 814 (1982)); see also infra Part II.B.

9. In this sense, this Article updates and corrects Jack Beermann's "critical analysis" of Section 1983 and qualified immunity, which concluded several decades ago that "legalistic analysis of $\S 1983$ " was largely “indeterminate." Jack M. Beermann, A Critical Approach to Section 1983 with Special Attention to Sources of Law, 42 STAN. L. REV. 51, 53 (1989).

10. LDF Statement on the Non-Indictment of Cleveland Police Officers in the Shooting Death of Tamir Rice, NAACP LEGAL DEFENSE FUND (Dec. 28, 2015), http://www.naacpldf.org/pressrelease/ldf-statement-non-indictment-cleveland-police-officers-shooting-death-tamir-rice [https://perma.cc/9KMQ-PCFA].

11. Matthew Segal, Opinion, Beyond \#BlackLivesMatter: Police Reform Must Be Bolstered by Legal Action, GUARDIAN (July 27, 2016), https://www.theguardian.com/commentisfree/2016/jul/27/beyond-black-lives-matter-police-reformlegal-action [https://perma.cc/J9EK-B6AX].

12. Jon O. Newman, Opinion, Here's a Better Way to Punish the Police: Sue Them for Money, WASH. POST (June 23, 2016), https://www.washingtonpost.com/opinions/heres-a-better-wayto-punish-the-police-sue-them-for-money/2016/06/23/c0608ad4-3959-11e6-9ccd-

d6005beac8b3_story.html [https://perma.cc/9R6N-323Z]; see also Aziz Huq, Revive Congressional Authority over Courts, 39 DEMOCRACY: J. IDEAS (Winter 2016), $\mathrm{http}: / /$ democracyjournal.org/magazine/39/revive-congressional-authority-over-courts 
This Article argues that it does not. Part I discusses the Court's three proffered justifications for qualified immunity, reconstructing the reasoning of each one and then explaining its legal flaws. Part II discusses the implications of this legal analysis going forward, with special attention to the Supreme Court's new elevation of qualified immunity to special certiorari status.

I.

\section{THE LEGAL JUSTIFICATIONS FOR QUALIFIED IMMUNITY}

The statute colloquially known as "Section 1983," because it is codified at 42 U.S.C. $§ 1983$, makes liable state actors who violate constitutional or other legal rights. It was first enacted during Reconstruction as a section of the 1871 Ku Klux Act, part of a suite of "Enforcement Acts" designed to help combat lawlessness and civil rights violations in the southern states. The statute originally provided:

That any person who, under color of any law, statute, ordinance, regulation, custom, or usage of any State, shall subject, or cause to be subjected, any person within the jurisdiction of the United States to the deprivation of any rights, privileges, or immunities secured by the Constitution of the United States, shall, any such law, statute, ordinance, regulation, custom, or usage of the State to the contrary notwithstanding, be liable to the party injured in any action at law, suit in equity, or other proper proceeding for redress; such proceeding to be prosecuted in the several district or circuit courts of the United States, with and subject to the same rights of appeal, review upon error, and other remedies provided in like cases in such courts, under the provisions of the act of the ninth of April, eighteen hundred and sixtysix, entitled "An act to protect all persons in the United States in their civil rights, and to furnish the means of their vindication"; and the other remedial law of the United States which are in their nature applicable in such cases. ${ }^{13}$

As currently codified in the U.S. Code, the statute provides:

Every person who, under color of any statute, ordinance, regulation, custom, or usage, of any State or Territory or the District of Columbia, subjects, or causes to be subjected, any citizen of the United States or other person within the jurisdiction thereof to the deprivation of any rights, privileges, or immunities secured by the Constitution and laws,

[https://perma.cc/6F9P-VCU5] (arguing that Congress "should narrow or abolish the doctrine of "qualified immunity"').

13. An Act to Enforce the Provisions of the Fourteenth Amendment to the Constitution of the United States, and for Other Purposes, ch. 22, § 1, 17 Stat. 13 (1871) (codified as amended at 42 U.S.C. $§ 1983$ (2012)). A few years later, Congress rephrased and reenacted the provision as Section 1979 of the Revised Statutes of 1874. An Act to Protect All Citizens in Their Civil and Legal Rights, ch. 114, 18 Stat. 335 (1875) (codified as amended at 42 U.S.C. $§ 1983$ (2012)). Formally, that is the statute that gives the provision force today. CALEB NELSON, STATUTORY INTERPRETATION 785-87, $786 \&$ n. 41 (2010). 
shall be liable to the party injured in an action at law, suit in equity, or other proper proceeding for redress, except that in any action brought against a judicial officer for an act or omission taken in such officer's judicial capacity, injunctive relief shall not be granted unless a declaratory decree was violated or declaratory relief was unavailable. For the purposes of this section, any Act of Congress applicable exclusively to the District of Columbia shall be considered to be a statute of the District of Columbia. ${ }^{14}$

Neither version of the text, you will notice if you wade through them, makes any reference to immunity. (The reference to the "same rights" and "other remedies" in the original statute pointed to the 1866 Civil Rights Act, which provided broad federal remedial authority, Supreme Court review, and presidential authority to direct prosecutions and use the military to enforce the Act. $)^{15}$

Yet that is not the end of the matter. Legal texts that seem categorical on their faces are frequently "defeasible"- that is, they are subject to implicit exceptions made by other rules of law. "No vehicles in the park" might forbid ambulances from entering, but a separate rule of law may nonetheless provide an exception for government vehicles or for responses to an emergency. ${ }^{17}$

Perhaps more to the point, legal provisions are often subject to defenses derived from common law. For example, the common-law rules of selfdefense, duress, and necessity can all apply to criminal statutes that do not even mention them. ${ }^{18}$ Similarly, I have elsewhere defended the current doctrine of state sovereign immunity even though it, too, is an unwritten defense that goes almost unmentioned in the text of the Constitution. ${ }^{19}$ So perhaps Section $1983^{20}$ permits such an unwritten immunity defense despite its seemingly categorical provisions for liability.

To say that an unwritten defense can exist, however, is not to say that any particular unwritten defense is in fact legally justified. Such defenses come from other legal sources and must be justified on their own legal terms. That is

14. 42 U.S.C. $§ 1983$. The equivalent federal cause of action has been subsequently supplied by federal common law, see Bivens v. Six Unknown Named Agents of Fed. Bureau of Narcotics, 403 U.S. 388 (1971), and one might imagine that it would have produced distinct questions of unwritten immunity, cf. Theodore Eisenberg, Section 1983: Doctrinal Foundations and an Empirical Study, 67 CORNELl L. REV. 482, 548 (1982). But so far, the Court has mechanically equated the two sets of immunities, Wilson v. Layne, 526 U.S. 603, 609 (1999), so this Article will not consider them separately.

15. Civil Rights Act of 1866, ch. 31, §§ 3, 8-10, 14 Stat. 27 (1866).

16. Baude \& Sachs, supra note 5, at 1101, 1107-08.

17. Id. at $1106-07$.

18. Id. at $1105-06$. (2017).

19. William Baude, Sovereign Immunity and the Constitutional Text, 103 VA. L. REV. 1

20. For ease of exposition and recognition, this Article refers to the statute anachronistically as "Section 1983" - not the Ku Klux Act, Section 1979, or its other nicknames - regardless of historical period. 
why it is so important to understand the ostensible legal basis for qualified immunity. After disentangling the Court's many immunity cases, three possible bases for the doctrine surface.

The first, which is perhaps the most well known, is that qualified immunity derives from a putative common-law rule that existed when Section 1983 was adopted. ${ }^{21}$ But this argument does not withstand historical scrutiny, and the Court has been inconsistent in adhering to it. If that argument fails, the cases suggest two alternative justifications that have not received enough notice. One is that qualified immunity is legitimate compensation for a different error the Court supposedly made earlier in construing the scope of Section 1983. The other is that qualified immunity derives from principles of fair notice analogous to the criminal law rule of lenity. Upon closer examination, none of these rationales can sustain the modern doctrine of qualified immunity.

Let us examine each one in turn.

\section{A. The Historical Good-Faith Defense}

To understand the first account of qualified immunity requires a few words about the historical transformation caused by Section 1983. Before the Civil War, suits for damages against government officials were not litigated

directly as constitutional torts. Rather, constitutional claims emerged as part of a suit to enforce general common-law rights. As Akhil Amar has helpfully summarized, "Plaintiff would sue defendant federal officer in trespass; defendant would claim federal empowerment that trumped the state law of trespass under the principles of the supremacy clause; and plaintiff, by way of reply, would play an even higher supremacy clause trump: Any federal empowerment was ultra vires and void" because the defendant acted unconstitutionally. ${ }^{22}$ (Such claims involved federal officials because until the enactment of the Fourteenth Amendment few constitutional prohibitions of consequence applied to state officers.)

For instance, a New York merchant might bring a trespass action, demanding \$100,000 against a U.S. military officer for taking command of his horses, mules, and wagons. The officer would respond that he had a lawful right to do so because of orders given as part of an authorized military action. The merchant would then respond that any such orders were unconstitutional under the Takings or Due Process Clauses, thus stripping the officer of his

21. Cf. Baude \& Sachs, supra note 5, at 1133-34 (discussing idea of "adoption rules").

22. Akhil Reed Amar, Of Sovereignty and Federalism, 96 YALE L.J. 1425, 1506 (1987). 
defense. $^{23}$ Constitutional rights were litigated through the procedural framework of general common-law torts, not as freestanding damages claims. ${ }^{24}$

Section 1983 changed this framework. It created a direct cause of action against state officials for "the deprivation of any rights... secured by the Constitution" 25 and thus eliminated the need to first allege a common-law claim or damages. In Hohfeld's terms ${ }^{26}$ most constitutional rights went from being treated as rules about power to being treated as duties. ${ }^{27}$ As a result, Section 1983 raised questions about how the new constitutional claims related to the old common-law claims, and whether the common law had any role to play in the new constitutional suits.

\section{The Court's Account}

The most widely known theory of qualified immunity draws upon this historical background in a general way, arguing that the immunity is a common-law backdrop that could be read into the statute-like, perhaps, the absolute immunities of legislative and judicial officials. The theory creates the backdrop by drawing analogies to the rules that governed common-law torts.

The Supreme Court's decision in Pierson v. Ray pioneered the key intellectual move. ${ }^{28}$ In 1961, several Mississippi police officers arrested a group of people, including Reverend Robert Pierson, under an anti-loitering law for refusing to leave a segregated bus terminal. ${ }^{29}$ In 1965, in a different case, the Supreme Court seemed to hold the Mississippi statute unconstitutional in very similar factual circumstances. ${ }^{30}$ In 1967, in Pierson v. Ray, the Court

23. This example is drawn from Mitchell v. Harmony, 54 U.S. (13 How.) 115 (1851), but there are many more, see, for example, Wise v. Withers, 7 U.S. (3 Cranch) 331 (1806).

24. Claims for equitable relief had a related but more complicated history, see, for example, Marsha S. Berzon, Securing Fragile Foundations: Affirmative Constitutional Adjudication in Federal Courts, 84 N.Y.U. L. REV. 681, 688-91 (2009); John F. Preis, In Defense of Implied Injunctive Relief in Constitutional Cases, 22 WM. \& MARY BILL RTS. J. 1 (2013), but this is beside the point for present purposes since qualified immunity applies to damages claims, not claims for equitable relief.

25. An Act to Enforce the Provisions of the Fourteenth Amendment to the Constitution of the United States, and for Other Purposes, ch. 22, § 1, 17 Stat. 13 (1871) (codified as amended at 42 U.S.C. $\S 1983$ (2012)). At the same time, the Fourteenth Amendment applied many more constitutional constraints to the states.

26. Wesley Newcomb Hohfeld, Some Fundamental Legal Conceptions as Applied in Judicial Reasoning, 23 YALE L.J. 16, 32-44 (1913).

27. Cf. John Harrison, The Constitutional Origins and Implications of Judicial Review, 84 VA. L. REV. 333, 340-41 (1998) ("Rules about duty and rules about power differ importantly, especially with respect to the consequences of their violation. ... Criminals are punished, and trespassers must provide compensation, but the law attaches no price to an act that fails to comply with a power rule."); see also John Harrison, Power, Duty, and Facial Invalidity, 16 U. PA. J. CONST. L. 501, 510 (2013).

28. Pierson v. Ray, 386 U.S. 547 (1967).

29. Id. at 549 .

30. Thomas v. Mississippi, 380 U.S. 524, 524 (1965). I write "seemed to" because the decision was a one-sentence summary reversal of the sort that Professor Alexander Bickel called "opinions that do not opine and ... per curiam orders that quite frankly fail to build the bridge between the authorities they cite and the results they decree." Alexander M. Bickel \& Harry H. Wellington, Legislative Purpose and the Judicial Process: The Lincoln Mills Case, 71 HARV. L. REV. 1, 3 (1957). 
then ruled that the police should not be held liable under the Fourth Amendment for the 1961 arrests. Why? Because in a common-law suit for false arrest, "a peace officer who arrests someone with probable cause is not liable for false arrest simply because the innocence of the suspect is later proved," and that could arguably be extended to "excusing him from liability for acting under a statute that he reasonably believed to be valid but that was later held unconstitutional." 31

The newer constitutional tort, the Court held, should be read the same way:

[Section] 1983 "should be read against the background of tort liability that makes a man responsible for the natural consequences of his actions." Part of the background of tort liability, in the case of police officers making an arrest, is the defense of good faith and probable cause. We hold that the defense of good faith and probable cause, which the Court of Appeals found available to the officers in the common-law action for false arrest and imprisonment, is also available to them in the action under [Section] 1983. ${ }^{32}$

On its face, one might have expected this reasoning to be limited to false arrests or other torts with similar elements, but the Court rapidly expanded it to executive action generally. ${ }^{33}$ One might also have expected this reasoning to support a subjective defense of good faith, but the Court has since transformed it into an objective analysis of "the objective reasonableness of an official's conduct, as measured by reference to clearly established law." ${ }^{34}$

In the course of transforming qualified immunity into its modern form, the Court did not always repeat this common-law "background" argument as frequently, perhaps because looking at the history would cause one to question the transformations. ${ }^{35}$ But in Filarsky $v$. Delia ${ }^{36}$ a more recent opinion by Chief Justice Roberts, the Court invoked the common-law background once again, suggesting that it remains an important grounding for the legitimacy of the doctrine. In that case, the contested issue was immunity for those who work with the government without being its employees. The Court ruled that such immunity was largely available to non-employees, but before doing so went out of its way to reinforce the historical theory of immunity:

At common law, government actors were afforded certain protections

31. Pierson, 386 U.S. at 555.

32. Id. at 556-57 (quoting Monroe v. Pape, 365 U.S. 167, 187 (1961)).

33. Scheuer v. Rhodes, 416 U.S. 232, 247 (1974) (" [S]ince the options which a chief executive and his principal subordinates must consider are far broader and far more subtle than those made by officials with less responsibility, the range of discretion must be comparably broad.").

34. Harlow v. Fitzgerald, 457 U.S. 800, 818 (1982).

35. For developments between Pierson and Harlow, see David Rudovsky, The Qualified Immunity Doctrine in the Supreme Court: Judicial Activism and the Restriction of Constitutional Rights, 138 U. PA. L. REV. 23, 38-42 (1989).

36. Filarsky v. Delia, 566 U.S. 377 (2012). 
from liability, based on the reasoning that "the public good can best be secured by allowing officers charged with the duty of deciding upon the rights of others, to act upon their own free, unbiased convictions, uninfluenced by any apprehensions." Our decisions have recognized similar immunities under $\S 1983$, reasoning that common law protections "“well grounded in history and reason' had not been abrogated 'by covert inclusion in the general language' of $\S 1983 . " 37$

Since the foundation of immunity had not been questioned by the parties, the passage's purpose is slightly unclear. The Court relied on history to answer the actual question presented (i.e., whether immunity should depend on employee status), ${ }^{38}$ so it is possible that the Court needed to first reassert that history was a useful guide to this area. In any event, it is emblematic of the Court's approach to official immunities: purportedly, at least, official immunities must be grounded in some kind of construction of the statute in light of its history rather than justified on sheer policy consequences.

Preliminarily, note that the Court's references to common law here are concrete and historically fixed. The Court is not using common law in the Benthamite sense, as being "nothing but an alias for "judge-made law." 39 Filarsky is thus consistent with the Court's previous insistence that "[w]e do not have a license to establish immunities from $\S 1983$ actions in the interests of what we judge to be sound public policy." ${ }^{40}$ It is also consistent with the Court's "reemphasi[s] that our role is to interpret the intent of Congress in enacting $\S 1983$, not to make a freewheeling policy choice, and that we are guided in interpreting Congress' intent by the common-law tradition." ${ }^{\prime 1}$

While "[i]t could be argued" that Section 1983 calls for "contemporary common law and equity principles," ${ }^{42}$ the Court has disavowed that argument as well. Instead, it looks to the traditional common law, asking whether those immunities "were so well established in 1871, when $\S 1983$ was enacted, that "we presume that Congress would have specifically so provided had it wished to abolish' them." 43

37. Id. at 383-84 (internal citations omitted) (quoting Wasson v. Mitchell, 18 Iowa 153, 155156 (1864); Imbler v. Pachtman, 424 U.S. 409, 418 (1976)) (citing WiLliam L. ProsSER, HANDBOOK OF THE LAW OF TORTS $\S 25$, at 150 (1941)).

38. Filarsky, 566 U.S. at 384-90.

39. Caleb Nelson, The Legitimacy of (Some) Federal Common Law, 101 VA. L. REV. 1, 15 (2015).

40. Tower v. Glover, 467 U.S. 914, 922-23 (1984).

41. Malley v. Briggs, 475 U.S. 335, 342 (1986).

42. Beermann, supra note 9, at $61 \mathrm{n} .69$ (emphasis added); see also id. ("Congress, the argument goes, knew that rules for such proceedings evolve and did not indicate an intention to freeze $\S 1983$ into the rules of 1871.”).

43. Buckley v. Fitzsimmons, 509 U.S. 259, 268 (1993) (quoting Pierson v. Ray, 386 U.S. 547, 554-55 (1967)). It is debatable whether this is an accurate citation of Pierson, which referred to the "prevailing view," Pierson, 386 U.S. at 555, and therefore can be read to focus on "modern rather than nineteenth century tort doctrine." Seth F. Kreimer, The Source of Law in Civil Rights Actions: Some Old Light on Section 1988, 133 U. PA. L. REV. 601, 609 (1985); see also Smith v. Wade, 461 U.S. 30, 
Similarly, the Court does not treat immunity as a question of "interstitial law" "44 that incorporates the law of the relevant state, even though it has done so for other procedural issues. ${ }^{45}$

\section{The Historical Problems}

The Court's account of common-law qualified immunity has several historical problems. First, there was no well-established, good-faith defense in suits about constitutional violations when Section 1983 was enacted, nor in Section 1983 suits early after its enactment. Second, to the limited extent a good-faith defense did exist in some common-law suits, it was part of the elements of a common-law tort, not a general immunity. Third, qualified immunity today is much broader than a good-faith defense.

\section{a. Legality Instead of Good Faith}

As many scholars of official liability have pointed out, lawsuits against officials for constitutional violations did not generally permit a good-faith defense during the early years of the Republic. ${ }^{46}$

A paradigmatic example is Chief Justice Marshall's 1804 opinion in Little v. Barreme, ${ }^{47}$ in which naval Captain George Little mistakenly captured a Danish boat, The Flying-Fish, and was subsequently sued. ${ }^{48}$ The Court thought it plain that federal law allowed the boat to be seized only if it was going to a French port, which it was not. ${ }^{49}$ But President Adams had issued broader instructions to seize boats both going to and coming from French ports, which the Court sympathetically noted were "much better calculated to give [the law]

34 n.2 (1983) (defending relevance of "modern tort decisions in construing $\S 1983$ "); David Achtenberg, Immunity Under 42 U.S.C. \& 1983: Interpretive Approach and the Search for the Legislative Will, 86 Nw. U. L. REV. 497, 525 (1992). But it is the Court's position now, anyway.

44. William Baude, Beyond DOMA, Choice of State Law in Federal Statutes, 64 STAN. L. REV. 1371, 1423-27 (2012).

45. Kreimer, supra note 43, at 615.

46. JAMES E. PFANDER, CONSTITUTIONAL TORTS AND THE WAR ON TERROR 3-14, 16-17 (2017); David E. Engdahl, Immunity and Accountability for Positive Governmental Wrongs, 44 U. COLO. L. REV. 1, 14-21 (1972); Ann Woolhandler, Patterns of Official Immunity and Accountability, 37 CASE W. RES. L. REV. 396, 414-22 (1987).

47. 6 U.S. (2 Cranch) 170 (1804); see also James E. Pfander \& Jonathan L. Hunt, Public Wrongs and Private Bills: Indemnification and Government Accountability in the Early Republic, 85 N.Y.U. L. REV. 1862, 1863 (2010) ("No case better illustrates the standards to which federal government officers were held than Little v. Barreme."). Again, the paradigmatic example before the Fourteenth Amendment was a federal official. See supra text following note 22.

48. Little, 6 U.S. (2 Cranch) at 176. The opinion does not explain who "Barreme" was. In case you were wondering (as I was), Francois Barreme was "the supercargo (i.e., the agent for the ship's owner.)” FREDERICK C. LEINER, MILLIONS FOR DEFENSE: THE SUBSCRIPTION WARSHIPS OF 1798, at 100 (2014). Thanks to Kevin Walsh and Ryan Williams for pointing me to this information.

49. Little, 6 U.S. (2 Cranch) at 177-78. 
effect," and without which it "was so obvious ... that the law would be very often evaded." 50

The question in Captain Little's case was whether his reliance on the President's instructions could "excuse him" him from liability even though the seizure was unlawful. ${ }^{51}$ The executive construction was a sympathetic one, and Chief Justice Marshall thought that the ship had been "seized with pure intention." 52 Nonetheless, the Court concluded, "the instructions cannot change the nature of the transaction, or legalize an act which without those instructions would have been a plain trespass. ${ }^{53}$ In other words, good-faith reliance did not create a defense to liability - what mattered was legality.

A personal aside by Chief Justice Marshall helps show the deep roots of the legality principle. Before he ultimately acquiesced in the rule established by the Court, Marshall explained, "[T] $]$ he first bias of my mind was very strong in favour of the opinion that though the instructions of the executive could not give a right, they might yet excuse from damages." 54 Even then, Marshall imagined creating an excuse only because "a distinction ought to be taken between acts of civil and those of military officers; and between proceedings within the body of the country and those on the high seas." 55

In other words, even when Marshall was tempted to rule in favor of the military officer abroad, he recognized the general principle of liability for domestic violations by civil officials - the circumstances that describe almost every modern qualified immunity case decided by the Court. ${ }^{56}$ As other scholars have noted, that "strict rule of personal official liability, even though its harshness to officials was quite clear," was a fixture of the founding era. ${ }^{57}$ To be sure, the harshness was mediated by a related practice: during the antebellum period officials also regularly petitioned Congress for indemnification and "succeeded in securing indemnifying private legislation in

50. Id. at 178 .

51. Id. The opinion refers to the seizure as "unlawful" rather than specifically "unconstitutional," though it certainly seems as though an unlawful seizure of a ship would have violated either the Fourth or Fifth Amendments (more likely the Fifth). See Nathan S. Chapman, Due Process Abroad, 112 Nw. U. L. REV. (forthcoming Dec. 2017) (discussing Little v. Barreme as a due process case); cf. Thomas Y. Davies, Recovering the Original Fourth Amendment, 98 MicH. L. REV. 547, 606 n.154 (1999) (denying that the Fourth Amendment applied to ships).

52. Little, 6 U.S. (2 Cranch) at 179.

53. Id.

54. Id.

55. Id; see also id. ("That implicit obedience which military men usually pay to the orders of their superiors, which indeed is indispensably necessary to every military system, appeared to me, strongly to imply the principle.").

56. See infra Appendix. One very recent case, Hernandez v. Mesa, 137 S. Ct. 2003 (2017), concerned a border patrol agent who shot a Mexican boy across the U.S.-Mexico border.

57. Engdahl, supra note 46, at 19. 
roughly sixty percent of cases in which they petitioned." 58 But that indemnification did not interrupt the courts' business of enforcing the law.

The original pattern of personal liability became more complicated over time, especially when the government officials were sued for common-law torts without constitutional claims. ${ }^{59}$ Even so, one could still find cases applying the founding-era principles throughout the nineteenth century. For instance, in 1891, the Supreme Judicial Court of Massachusetts, through Justice Holmes, held that members of a town health board could be held liable for mistakenly killing an animal they thought to be diseased, even when government commissioners had ordered the killing. ${ }^{60}$

More importantly, after Section 1983 was enacted, the Court specifically rejected the application of a good-faith defense to constitutional suits under that specific statute. The key case is Myers v. Anderson, where the Court held that a state statute violated the Fifteenth Amendment's ban on racial discrimination in voting. ${ }^{61}$ The case was brought under Section 1983, and the state officials argued, among other things, that they could not be liable for money damages if they had in good faith thought the statute constitutional. ${ }^{62}$ Section 1983, they claimed, was intended to preserve "traditional limits" such as a common-law requirement "that malice be alleged" in voting rights cases. ${ }^{63}$

The Court did not spend much time rejecting this argument in its opinion, but it did reject it. The Court observed that " $[\mathrm{t}]$ he nonliability in any event of the election officers for their official conduct is seriously pressed in

58. Pfander \& Hunt, supra note 47 , at 1867 . As the authors candidly note, the 60 percent estimate may not capture all of the unsuccessful petitions or the potentially unsuccessful claims. Id. at 1867 n.23.

59. See Engdahl, supra note 46, at 48-55; Richard H. Fallon, Jr. \& Daniel J. Meltzer, New Law, Non-Retroactivity, and Constitutional Remedies, 104 HARV. L. REV. 1731, 1749-50, 1833 (1991); Louis L. Jaffe, Suits Against Governments and Officers: Damage Actions, 77 HARV. L. REV. 209, 220-22 (1963); Woolhandler, supra note 46, at 436-57.

60. Miller v. Horton, 26 N.E. 100, 100 (Mass. 1891); see also Yosal Rogat, Mr. Justice Holmes: A Dissenting Opinion, 15 STAN. L. REV. 3, 29-31 (1962) (questioning decision); John H. Wigmore, Justice Holmes and the Law of Torts, 29 HARV. L. REV. 601, 615-16 (1916) (praising decision)

61. Myers v. Anderson, 238 U.S. 368, 378-79 (1915); see also Kreimer, supra note 43, at 609 n.34 (discussing Anderson); Woolhandler, supra note 46, at 457 (same). $8-10)$.

62. See Brief for Plaintiffs in Error at 23-45, Myers v. Anderson, 238 U.S. 368 (1915) (Nos.

63. Id. at 34-35. Interestingly, the state officials waffled on whether the good-faith defense they alleged was constitutionally required. In their initial brief, the officials conceded: "[W]e are not making here any contention that Congress might not, if it had chosen to do so, have provided for liability in damages on the part of the Election Officials, in a case of this sort without proof of malice or corrupt motive." Id. at 35. But in a supplemental brief, they argued that if the statute imposed strict liability, "it is not appropriate legislation under the second section of the Fifteenth Amendment" and "would completely destroy the autonomy of the states, and would in effect deprive them of a republican form of government secured to them by the Constitution of the United States." Supplemental Brief for Plaintiffs in Error at 3, Myers v. Anderson, 238 U.S. 368 (1915) (Nos. 8-10); see infra Part II.A. 
argument" ${ }^{64}$ by the appellants. But, it concluded, this argument (as well as a substantive argument that the Fifteenth Amendment does not apply to municipal elections) was "fully disposed of by the ruling this day made in the Guinn Case and by the very terms of $\S 2004$, Rev. Stat., Comp. Stat. 1913, $\S 3966$, when considered in the light of the inherently operative force of the 15th Amendment as stated in the case referred to. ${ }^{" 65}$ In other words, there was no good-faith defense.

While the Court did not elaborate, it is possible that the Court thought that the text of Section 1983 did not permit unwritten defenses at all. It is also possible, however, that the Court agreed with the lower court's analysis upholding liability. The lower court had been slightly more specific in denying the good-faith defense:

The common sense of the situation would seem to be that, the law forbidding the deprivation or abridgment of the right to vote on account of race or color being the supreme law, any state law commanding such deprivation or abridgment is nugatory and not to be obeyed by any one; and any one who does enforce it does so at his known peril and is made liable to an action for damages by the simple act of enforcing a void law to the injury of the plaintiff in the suit, and no allegation of malice need be alleged or proved. ${ }^{66}$

This is exactly the logic of the founding-era cases, ${ }^{67}$ alive and well in the federal courts after Section 1983's enactment. It was not until later in the twentieth century that the Court first grafted a good-faith defense to the constitutional cause of action.

\section{b. Not a Freestanding Defense}

This problem with the Court's qualified immunity doctrine is well known. That is why in Filarsky and earlier cases the Court did not point to a good-faith defense from constitutional causes of action but rather from common-law causes of action. But there is an additional problem. Even to the extent that these cases could be imported to the cause of action under Section 1983, they generally do not describe a freestanding common-law defense, like state

64. Myers, 238 U.S. at 378.

65. Id. at 378-79. Guinn v. United States, 238 U.S. 347 (1915) was a criminal conspiracy prosecution that did not discuss immunity. Section 2004 explicitly confirmed that the right to vote extends to municipal elections. An Act to Enforce the Right of Citizens of the United States to Vote in the Several States of this Union, and for Other Purposes, ch. 114, § 1, 16 Stat. 140 (1870); see also Guinn, 238 U.S. at 355-36 (quoting Section 2004).

66. Anderson v. Myers, 182 F. 223, 230 (C.C.D. Md. 1910) (emphasis added).

67. See, e.g., Engdahl, supra note 46, at 18 (The public official "was required to judge at his peril whether his contemplated act was actually authorized ... [and] judge at his peril whether ... the state's authorization-in-fact ... was constitutional.”). 
sovereign immunity. ${ }^{68}$ Instead, those cases mostly describe the individual elements of particular common-law torts.

This distinction is important because an element of a specific tort does not provide evidence of a more general backdrop that one would expect to export to other claims, let alone from common law to constitutional claims. For instance, a Fourteenth Amendment antidiscrimination claim requires the plaintiff to demonstrate discriminatory intent by the defendant. ${ }^{69}$ But it does not follow that intent-let alone discriminatory intent-is an element of a due process claim. ${ }^{70}$ Similarly, bad faith and flagrancy were simply elements of certain torts brought against public officials. It did not follow that they were elements of all torts or all constitutional claims against public officials.

For instance, one of the earliest Supreme Court cases to discuss the negative effects of damages against officers in close cases is the admiralty decision The Marianna Flora. ${ }^{71}$ In that case, the Court declined to "introduce a rule harsh and severe in a case of first impression." " However, the Court considered these harsh effects when defining the substantive rules of capture, which were within the Court's general powers of "conscientious discretion" specially applicable to its admiralty jurisdiction. The Court tethered its reasoning to specific facts about rules of capture in admiralty, not to a general defense.

The role of good faith as an element of specific torts, rather than as a defense, is even more apparent in Pierson, where the Court pointed to the elements of the false arrest tort at common law. ${ }^{74}$ The Court cited the Second Restatement of Torts, which described a "privilege[] to arrest," 75 an Eighth Circuit case arising in diversity that applied Missouri law consistent with the Second Restatement, ${ }^{76}$ and a torts treatise to similar effect. ${ }^{77}$

Interestingly, Prosser's 1941 treatise, a few pages after the portion cited in Filarsky, notes using the present tense that "courts are being driven slowly" to

68. Sovereign immunity, which keeps states from being sued without their consent, is "a background rule of procedure like waiver or precedent or capacity to sue" that applies regardless of the substance of the suit. See Baude, supra note 19, at 8-9.

69. Washington v. Davis, 426 U.S. 229, 239-42 (1976).

70. See Cty. of Sacramento v. Lewis, 523 U.S. 833, 849 (1998) (noting that injuries "following from something more than negligence but "less than intentional conduct" will sometimes give rise to a due process claim).

71. 24 U.S. (11 Wheat.) 1 (1826) (Story, J.).

72. Id. at 56 .

73. Id. at 54-55 ("Even in cases of marine torts, independent of prize, Courts of admiralty are in the habit of giving or withholding damages upon enlarged principles of justice and equity, and have not circumscribed themselves within the positive boundaries of mere municipal law. They have exercised a conscientious discretion upon the subject.").

74. Pierson v. Ray, 386 U.S. 547, 555 (1967)

75. RESTATEMENT (SECOND) OF TORTS $§ 121$ (AM. LAW INST. 1965).

76. Missouri ex rel. Ward v. Fid. \& Deposit Co. of Md., 179 F.2d 327, 331 (8th Cir. 1950).

77. 1 FOWLER V. HARPER, FLEMING JAMES, JR. \& OSCAR S. GRAY, HARPER, JAMES AND GRAY ON TORTS $\S 3.18$, at 412 (3d ed. 2006). 
extend a good-faith immunity "[e]ven as to officers acting under an unconstitutional statute." 78 But the "slow[]"79 evolution Prosser describes almost entirely post-dated the enactment of Section 1983. Only two of the cases he cited were from before 1871 , one on each side of the immunity question, suggesting that any good-faith defense was protean and contested at best. ${ }^{80}$

To be sure, because some constitutional doctrine itself borrows concepts or rules from the common law, it is possible to envision the elements of an individual common-law tort in that garb. But that should occur on the merits side of the ledger; there is no justification for reading it into the statutory remedy.

\section{c. The Mismatch Problem}

Finally, even if one were to grant the existence of a good-faith defense and import it to constitutional claims, modern immunity cases have distorted those common-law rules to a troubling degree. First, qualified immunity is now applied "across the board" to all constitutional claims - and perhaps to statutory claims as well ${ }^{81}$-regardless of "the precise character of the particular rights," ${ }^{, 2}$ rather than being limited to the kinds of claims where good faith was traditionally relevant. Second, instead of the subjective inquiry into intent or motive that marked the good-faith inquiry, qualified immunity has become an objective standard based on case law. ${ }^{83}$ This means that even the official who acts in bad faith is entitled to the defense if a different official could have

78. William L. Prosser, HANDBOOK OF the LAW OF TORTS 153-54 (1941) (emphasis added).

79. Id.

80. Compare Kelly v. Bemis, 70 Mass. (70 Gray) 83, 84 (Mass. 1855) (liability for action under unconstitutional statute), with State v. McNally, 34 Me. 210, 221 (Me. 1852) (stating, in criminal appeal, that "[i]t was no part of the officer's duty to examine into and decide upon the constitutionality or construction of the statute which authorized his warrant").

81. See Harlow v. Fitzgerald, 457 U.S. 800, 818 (1982) (emphasis added) ("We therefore hold that government officials performing discretionary functions, generally are shielded from liability for civil damages insofar as their conduct does not violate clearly established statutory or constitutional rights of which a reasonable person would have known."); Mitchell N. Berman, R. Anthony Reese \& Ernest A. Young, State Accountability for Violations of Intellectual Property Rights: How to "Fix" Florida Prepaid (and How Not to), 79 TEX. L. REV. 1037, 1123 (2001) (“[T]he lower federal courts have held the qualified immunity defense to be available against a wide variety of federal statutory claims. Even though qualified immunity is plainly available as a defense to some statutory claims, however, the courts have acknowledged that the defense is incompatible with certain federal statutes."); see also Kathleen Lockard, Note, Qualified Immunity as a Defense to Federal Wiretap Act Claims, 68 U. CHI. L. REV. 1369, 1392-1400 (2001) (arguing against qualified immunity defense to wiretap claims).

82. Anderson v. Creighton, 483 U.S. 635, 642-43 (1987). As late as 1963, Professor Jaffe assumed that the growing discretionary official immunity would nonetheless exclude "the historic liability of sheriffs and peace officers" and "[a] police officer, for example, who negligently operates a Black Maria." Jaffe, supra note 59, at 221-22. It does not.

83. Harlow, 457 U.S. at $816-18$. 
reasonably made the mistake. ${ }^{84}$ Third, as this Article will discuss in more depth, qualified immunity's objective defense has become increasingly protective, outstripping other comparable defenses ${ }^{85}$ and leading the Court on the kind of pro-immunity crusade that it normally reserves for legal edicts like the Anti-Terrorism and Effective Death Penalty Act and the Federal Arbitration Act. $^{86}$

While the Court may not cop to the full force of these historical critiques, some Justices have acknowledged elements of them. For instance, in 1992 Justice Kennedy complained that "qualified immunity for public officials" had "diverged to a substantial degree from the historical standards." $87 \mathrm{He}$ specifically noted that it was "something of a misnomer to describe the common law as creating a good-faith defense; we are in fact concerned with the essence of the wrong itself, with the essential elements of the tort." ${ }^{\prime 8}$ Justice Kennedy found these deviations problematic because immunity doctrine is supposed to be "rooted in historical analogy, based on the existence of common-law rules in 1871, rather than in 'freewheeling policy choice[s]." "89

Joining a dissenting opinion six years later, Justice Thomas also endorsed a historical criticism of qualified immunity, observing that "our treatment of qualified immunity under 42 U.S.C. $\S 1983$ has not purported to be faithful to the common-law immunities that existed when $\S 1983$ was enacted, and that the statute presumably intended to subsume." 90 And just last term, Justice Thomas wrote for himself to observe that "[i]n further elaborating the doctrine of qualified immunity for executive officials ... we have diverged from the historical inquiry mandated by the statute" and "have not attempted to locate that standard in the common law as it existed in 1871." $" 91$

But perhaps there is another justification. Indeed, both of these Justices have also joined many of the Court's qualified immunity decisions. While the historical justification for qualified immunity has attracted the most attention and controversy, the Court's opinions contain two alternative legal rationales. Each of these rationales is sufficiently plausible to warrant consideration on its own terms. Let us turn to them next.

84. See Anderson, 483 U.S. at 641; see also David E. Pozen, Constitutional Bad Faith, 129 HARV. L. REV. 885, 898-99 (2016) (noting that through qualified immunity doctrine, the Court has "disavow[ed] the core conception of bad faith in its efforts to police the police").

85. See infra Part I.C.

86. Infra Part II.B.

87. Wyatt v. Cole, 504 U.S. 158, 170 (1992) (Kennedy, J., concurring).

88. Id. at 172 .

89. Id. at 170 (quoting Malley v. Briggs, 475 U.S. 335, 342 (1986)).

90. Crawford-El v. Britton, 523 U.S. 574, 611 (1998) (Scalia, J., dissenting). For further discussion, see infra Part I.B.

91. Ziglar v. Abbasi, 137 S. Ct. 1843, 1871 (2017). Citing an earlier version of this Article, Justice Thomas also wrote that "some evidence supports the conclusion that common-law immunity as it existed in 1871 looked quite different from our current doctrine." Id. 


\section{B. The Two-Wrongs-Make-A-Right Theory}

\section{The Crawford-El Account}

One of the two alternative legal justifications for qualified immunity is in a surprisingly obscure dissenting opinion in Crawford-El v. Britton. In Crawford-El, the Court rejected the application of a heightened pleading standard in qualified immunity cases. ${ }^{92}$ Justice Scalia, joined by Justice Thomas, dissented. Justice Scalia did not really maintain that the pleading standard could be justified on its own terms but instead argued instead that while qualified immunity might be wrong, it was a wrong justified by an earlier wrong in interpreting the statute. ${ }^{93}$

Our qualified immunity jurisprudence is inconsistent with the intended meaning of the statute, Justice Scalia conceded. ${ }^{94}$ But qualified immunity operates as a defense to the scope of liability under Section 1983, and we have so misinterpreted Section 1983 that qualified immunity is a fair enough response.

Here is the critical paragraph:

[O]ur treatment of qualified immunity under 42 U.S.C. $§ 1983$ has not purported to be faithful to the common-law immunities that existed when $\S 1983$ was enacted, and that the statute presumably intended to subsume. That is perhaps just as well. The $\S 1983$ that the Court created in 1961 bears scant resemblance to what Congress enacted almost a century earlier. I refer, of course, to the holding of Monroe $v$. Pape, which converted an 1871 statute covering constitutional violations committed "under color of any statute, ordinance, regulation, custom, or usage of any State," into a statute covering constitutional violations committed without the authority of any statute, ordinance, regulation, custom, or usage of any State, and indeed even constitutional violations committed in stark violation of state civil or criminal law. As described in detail by the concurring opinion of Judge Silberman in this case, Monroe changed a statute that had generated only 21 cases in the first 50 years of its existence into one that pours into the federal courts tens of thousands of suits each year, and engages this Court in a losing struggle to prevent the Constitution from degenerating into a general tort law. (The present suit, involving the constitutional violation of misdirecting a package, is a good enough example.) Applying normal common-law rules to the statute that Monroe created would carry us further and further from what any sane Congress could have enacted.

We find ourselves engaged, therefore, in the essentially legislative activity of crafting a sensible scheme of qualified immunities for the

92. Crawford-El, 523 U.S. at 574.

93. Id. at 611-12 (Scalia, J., dissenting).

94. Id. 
statute we have invented-rather than applying the common law embodied in the statute that Congress wrote. ${ }^{95}$

Justice Scalia's theory is an example of what various scholars have called "compensating adjustments" 96 or "equilibrium adjustments," Court will correct the course of an old doctrine by inventing a new one that tacks back the other way.

Such adjustments should be familiar to those who have read Justice Scalia's other opinions about official liability. In the 1971 decision Bivens $v$. Six Unknown Named Narcotics Agents, ${ }^{98}$ the Supreme Court recognized a cause of action for constitutional damages against federal officers, analogous to the Section 1983 cause of action against state officers. In subsequent cases about the scope of the Bivens action, Justice Scalia repeatedly and uniformly refused to recognize it. He did not attempt to justify these votes on Bivens's own terms, but rather on the grounds that Bivens was a mistake. Because there was no statutory basis for the Court's original decision (there was and is no statute equivalent to Section 1983 for federal officers), he dismissed Bivens as a "relic of the heady days in which this Court assumed common-law powers to create causes of action," an approach it had since "abandoned." 99

Under this theory of qualified immunity, it does not matter whether the doctrine can be justified on first principles. It is a judicially invented immunity for a judicially "invented" statute. ${ }^{100}$ Two wrongs, Justice Scalia might have said, can make a right. ${ }^{101}$

\section{The "Under Color of" Problem}

This second theory suffers from two legal deficiencies. The first problem is that Justice Scalia's premise - that Monroe v. Pape was wrongly decidedappears to be wrong. Monroe v. Pape confronted the tricky question of when illegal executive action is covered by Section $1983 .{ }^{102}$ The statute refers to

95. Id. at 611-12 (internal citations omitted).

96. See, e.g., Adrian Vermeule, Hume's Second-Best Constitutionalism, 70 U. CHI. L. REV. 421, 421-22 (2003); Ernest A. Young, Making Federalism Doctrine: Fidelity, Institutional Competence, and Compensating Adjustments, 46 WM. \& MARY L. REV. 1733, 1739 (2005).

97. Orin S. Kerr, An Equilibrium-Adjustment Theory of the Fourth Amendment, 125 HARV. L. REV. 476, 478 (2011).

98. 403 U.S. 388 (1971).

99. Corr. Servs. Corp. v. Malesko, 534 U.S. 61, 75 (2001) (Scalia, J., concurring); see also Minneci v. Pollard, 565 U.S. 118, 131-32 (2012) (Scalia, J., concurring); Wilkie v. Robbins, 551 U.S. 537, 568 (2007) (Thomas, J., concurring). One can, therefore, imagine a separate and distinct twowrongs-make-a-right argument for qualified immunity in the Bivens context, although to date, the Court has just mechanically equated immunities under Bivens with immunities under Section 1983. See supra note 15.

100. Crawford-El, 523 U.S. at 611-12 (Scalia, J., dissenting).

101. Cf. Antonin Scalia, Two Wrongs Make a Right: The Judicialization of Standardless Rulemaking, Regulation, July-Aug. 1977, at 38. But see Am. Trucking Ass'n v. Smith, 496 U.S. 167, 204 (1990) (Scalia, J., concurring) (“[T]wo wrongs do not make a right.”).

102. 365 U.S. 167 (1961). 
action taken "under color of" state law. ${ }^{103}$ Although this obviously applies to action that is authorized by state law, does it apply to action that is illegal as a matter of state law? Monroe v. Pape held that illegal action is indeed covered, and Justice Scalia later disagreed. ${ }^{104}$

Justice Scalia instead endorsed Justice Frankfurter's dissent in Monroe. ${ }^{105}$ That is often a good practice. Frankfurter was a perspicacious skeptic in federal jurisdiction cases (think of his Lincoln Mills dissent, ${ }^{106}$ his Tidewater dissent, ${ }^{107}$ and the fact that the first edition of Hart and Wechsler was dedicated to him ${ }^{108}$ ). Moreover, his position in Monroe has an intuitive appeal: many things that are unconstitutional are also illegal as a matter of state law. The Constitution does not let officers break into your house and harass you for no reason, but neither does battery law or the code for the use of force. So when an officer acts contrary to both the law of Illinois and the Constitution, does he really act "under color" of the law of Illinois?

This position makes sense, and one can see why Justices Scalia and Frankfurter might have held it as a hypothesis ${ }^{109}$-it was my initial hypothesis as well. The problem is that there is historical reason to doubt it. Section 1983 provides liability for those who act "under color of" state law-not merely "under" it or "consistent with" it — and it turns out that "under color of" is a longstanding legal term that encompasses false claims of legal authority.

As Steven Winter has recounted, the usage goes back more than 500 years, when an English bail bond statute voided obligations taken by sheriffs "by colour of their offices" without complying with a statutory procedure. The English court concluded that to act "by colour of" one's office (or "colore officii sui") included an illegal act. The phrase "signifies an act badly done under countenance of an office, and it bears a dissembling visage of duty, and is properly called extortion." 110 Subsequent decisions from American courts in the nineteenth century similarly agreed that "under color of law referred to

103. 42 U.S.C. $\S 1983$ (2012).

104. Crawford-El, 523 U.S. at 611-12 (Scalia, J., dissenting).

105. Id. (citing Monroe, 365 U.S. at 224-25 (Frankfurter, J., dissenting)).

106. Textile Workers Union v. Lincoln Mills, 353 U.S. 448, 475-77 (1957) (Frankfurter, J., dissenting).

107. Nat'l Mut. Ins. Co. v. Tidewater Transfer Co., 337 U.S. 582, 652 n.3 (1949) (Frankfurter, J., dissenting).

108. Henry M. Hart, JR. \& Herbert WeChSler, The Federal COURT AND the Federal SYSTEM, at ix (1st ed. 1953).

109. Justice Frankfurter did not rely on much historical evidence, Steven L. Winter, The Meaning of "Under Color of" Law, 91 MiCH. L. REV. 323, 325 (1992), but his position was subsequently defended by Eric H. Zagrans, "Under Color of" What Law: A Reconstructed Model of Section 1983 Liability, 71 VA. L. REV. 499 (1985) (cited in Crawford-El v. Britton, 93 F.3d 813, 830 (D.C. Cir. 1996) (Silberman, J., concurring)).

110. Winter, supra note 109, at 344 (quoting Dive v. Manningham, 1 Plowden Rep. 60, 67-68, 75 Eng. Rep. 65, 108 (Common Bench 1551)). 
official action without proper authority." 111 So "under color of" seems to perfectly include police officers and other officials who abuse or exceed their state-granted authority.

There is also evidence that the original framers of the Ku Klux Act understood the phrase in its traditional sense. Professor David Achtenberg has argued that there is circumstantial confirmation from the way the statute was drafted: Representative Shellabarger oversaw the insertion of the phrase "under color of" to replace the phrase "under pretense of." 112 Yet Shellabarger was more radical than the previous drafter, and his changes consistently broadened the availability of relief, so it seems unlikely that "under color of" was supposed to be more limited than "under pretense of," the phrase that it replaced. ${ }^{113}$ To be sure, Justice Scalia likely would not have cared about drafting history that is inconsistent with the apparent meaning of the text, but he did give weight to an established meaning of legal terms of art. ${ }^{114}$

In his Crawford-El dissent, Justice Scalia implied that his skepticism was bolstered by a more practical intuition that Monroe v. Pape had wrought a radical change to the meaning of Section 1983. As quoted above, he described Monroe as having "changed a statute that had generated only 21 cases in the first 50 years of its existence into one that pours into the federal courts tens of thousands of suits each year," 115 implying that the vast rise of constitutional torts in the second half of the twentieth century was proof that Monroe was wrongly decided. Some commentary by Monroe's supporters furthers the impression that the case was revolutionary. ${ }^{116}$

Let us put aside the point that Justice Scalia's numbers may be overstated: in the first fifty years there were fewer cases of all kinds, and Justice Scalia did not tell us the fraction of early Section 1983 suits. ${ }^{117}$ More fundamentally, there

111. Id. at 359 (emphasis omitted). Winter argues that, by contrast, "Zagrans' analysis of the legislative history proceeded in a historical vacuum: it is as if the phrase originated in the Reconstruction civil rights statutes, as if its legal significance were solely a matter of the intention of the Congress that so employed it." Id. at 325.

112. David Achtenberg, A "Milder Measure of Villainy": The Unknown History of 42 U.S.C. $\S 1983$ and the Meaning of "Under Color of" Law, 1999 UTAH L. REV. 1, 59-60 (1999).

113. Id. at 56-60. Achtenberg argues that, by contrast, Zagrans misunderstood the drafting history of Section 1983. Id. at 4 n.13, 5 n.18, 22 n.151.

114. See Antonin Scalia, Common-Law Courts in a Civil Law System: The Role of United States Federal Courts in Interpreting the Constitution and Laws, in A MATTER OF INTERPRETATION 29-37 (Amy Gutmann ed., 1997).

115. Crawford-El v. Britton, 523 U.S. 574, 611 (Scalia, J., dissenting) (relying on Crawford-El v. Britton, 93 F.3d 813, 829 (D.C. Cir. 1996) (Silberman, J., concurring)).

116. See, e.g., Karen M. Blum, Section 1983 Litigation: The Maze, The Mud, and the Madness, 23 WM. \& MARY BILL RTS. J. 913, 913 (2015) (footnotes omitted) ("Some of us were there at the 'founding,' and I don't mean in 1871 when 42 U.S.C. $§ 1983$ was originally enacted as the Ku Klux Klan Act, but in 1961, when the Court decided Monroe v. Pape."); Pamela S. Karlan, Foreword: Democracy and Disdain, 126 HARV. L. REV. 1, 25 (2012) (describing "[t]he innovation in Justice Douglas's opinion").

117. See Theodore Eisenberg \& Stewart Schwab, The Reality of Constitutional Tort Litigation, 72 CORNELL L. REV. 641, 662-68 (1987). 
is another, more modest explanation for the small number of early Section 1983 suits: there were not many judicially recognized constitutional rights for decades after Reconstruction. It was not until 1925 that the Supreme Court incorporated First Amendment protections against the states, ${ }^{118}$ and not until 1949 that the Court confirmed that "the core of the Fourth Amendment" was incorporated. ${ }^{119}$ Even if one thinks-as I do-that incorporation was commanded by the original meaning of the Fourteenth Amendment, ${ }^{120}$ it is still true that incorporation was not well received in the courts. ${ }^{121}$ Thus, it is little surprise that there weren't as many suits.

\section{The Mismatch Problem}

There is a second and more important problem with Justice Scalia's argument that two wrongs make a right. Even if we accept its premise as true, the results ought to be nothing like the modern regime of qualified immunity. If Justice Frankfurter was right about Monroe v. Pape, the resulting immunity ought to be nearly the opposite of the immunity regime we now have.

To see why, we must first reconstruct Justice Frankfurter's position, on which Justice Scalia relies. ${ }^{122}$ As a first approximation, Justice Frankfurter thought that an official acts "under color of" state law when his conduct is authorized by that law, and not when it is illegal. ${ }^{123}$ But Frankfurter's position had some additional subtleties. In many cases it will be unclear exactly whether a given course of conduct is legal under state law. In other cases it is possible that conduct will be unauthorized as a matter of the written statutes, but nonetheless permitted as a practical matter. And Section 1983 cares about unwritten law just as written law, since it treats "customs" or "usages" the same as "statutes." 24

118. Gitlow v. New York, 268 U.S. 652 (1925).

119. Wolf v. Colorado, 338 U.S. 25, 27 (1949). The Court thought that core was "[t]he security of one's privacy against arbitrary intrusion by the police," but not the exclusionary rule. Id.

120. See generally AKHIL REED AMAR, THE BILL OF RIGHTS: CREATION AND ReCONSTRUCTION (1998); Christopher R. GREen, EQUAl CitizENSHIP, CiVIL RIGHTS, AND THE CONSTITUTION: THE ORIGINAL SENSE OF THE PRIVILEGES OR IMMUNITIES CLAUSE (2015).

121. Louise Weinberg, The Monroe Mystery Solved: Beyond the "Unhappy History" Theory of Civil Rights Litigation, 1991 BYU L. REV. 737, 745-48 (1991) provides a similar explanation, as does Ilan Wurman, Qualified Immunity and Statutory Interpretation, 37 SEATTLE U. L. REV. 939, 977 (2014). See also 1 NAHMOD, supra note 1, at § 2:2 (footnotes omitted) ("Restrictive application of the state action doctrine, a narrow reading of the Fourteenth Amendment's privileges or immunities clause, a similarly narrow reading of $\S 1983$ 's jurisdictional counterpart, and the Supreme Court's refusal to incorporate completely the provisions of the Bill of Rights were jointly responsible for the dormancy of $\S 1983$ from the time of its enactment to the year 1961.").

122. Justice Frankfurter did not rely on much historical evidence, Winter, supra note 109, at 325, but Judge Silberman relied on Eric H. Zagrans's subsequently published defense of the Frankfurter position: "Under Color of" What Law: A Reconstructed Model of Section 1983 Liability, supra note 109 (cited in Crawford-El v. Britton, 93 F.3d 813, 830 (D.C. Cir. 1996) (Silberman, J., concurring)).

123. Monroe v. Pape, 365 U.S. 167, 241-42 (Frankfurter, J., dissenting).

124. 42 U.S.C. $\S 1983$ (2012). 
Justice Frankfurter admitted all of this, ${ }^{125}$ but he also had the insight that state remedial regimes and state courts can help us sort out authorized from unauthorized conduct. When a plaintiff seeks relief in state court under state law, we learn something about the legal status of the official's conduct. Consider the following four possibilities under Frankfurter's view:

1. If the state holds the conduct lawful, then we now know that a federal suit can be brought.

2. If the state holds the conduct illegal and provides a remedy, then the plaintiff will be compensated. A Section 1983 suit will be unavailable, but it will also be unneeded.

3. If the state holds the conduct illegal but nonetheless refuses to provide a remedy because of some official immunity, that establishes that the official did indeed act under color of state law. ${ }^{126} \mathrm{~A}$ federal suit can be brought here as well.

4. Finally, if the state holds that there is no remedy for generally applicable procedural reasons, ${ }^{127}$ we have learned nothing about the official's legal status.

Despite the importance of a possible state suit, Justice Frankfurter did not think that the statute contained an exhaustion requirement, stressing that "[p]rosecution to adverse judgment of a state-court damage claim cannot be made prerequisite to [Section 1983] relief." 128 If an official's legal status is clear enough from the text of state statutes or municipal ordinances, a federal court can consider the case straightaway. ${ }^{129}$ But in the "admittedly more difficult ones" that lay "[b]eyond these cases," 130 the court could presumably take guidance from the state's remedial regime. ${ }^{131}$

The Frankfurter regime thus has an internal logic. When the state remedies its officials' own wrongs, there is no need for federal liability. When the state legalizes or immunizes an official's conduct, federal law supplies a forum for constitutional adjudication. On this view, Section 1983 creates a

125. Monroe, 365 U.S. at 245-46 (Frankfurter, J., dissenting).

126. Id. at 211; cf. The Civil Rights Cases, 109 U.S. 3, 17 (1883) (emphasis added) ("The wrongful act of an individual, unsupported by any [State] authority, is simply a private wrong, or a crime of that individual; an invasion of the rights of the injured party, it is true, whether they affect his person, his property, or his reputation; but if not sanctioned in some way by the State, or not done under State authority, his rights remain in full force, and may presumably be vindicated by resort to the laws of the State for redress.").

127. Monroe, 365 U.S. at 245 (Frankfurter, J., dissenting) ("Section [1983] was not designed to cure and level all the possible imperfections of local common-law doctrines, but to provide for the case of the defendant who can claim that some particular dispensation of state authority immunizes him from the ordinary processes of the law.”).

128. Id.

129. Id. at 246.

130. Id.

131. The Court has since incorporated this insight in some of its procedural due process cases, even if not into Section 1983 itself. See Dist. Att'y's Office for the Third Judicial Dist. v. Osborne, 557 U.S. 52, 71 (2009); Zinermon v. Burch, 494 U.S. 113, 125 (1990). 
federal forum when states refuse to do so for self-interested reasons, and thus moves closer to the oft-recited (though sometimes breached) principle that "every right, when withheld, must have a remedy, and every injury its proper redress." 132 The "under color of" state law requirement then withholds that forum where it would be redundant with state tort law.

Frankfurter's position does not yield modern qualified immunity doctrine, nor does it require any federal immunities. A government's grant of immunity is a sign that the officer is acting partly under the authority of that government. Thus, immunities in state law are used as a trigger for liability.

Rather, under Frankfurter's view, Section 1983 fills in a remedial gap: it provides a federal forum for conduct legalized or immunized by the state. Yet qualified immunity entirely ignores both state liability and state immunity. A devotee of the Frankfurter position ought to analyze qualified immunity (if at all) by reference to state law to see where Monroe v. Pape has resulted in double tort coverage. That would mean denying immunity in cases where states grant it, while granting immunity only in cases where states deny it. Yet modern qualified immunity doctrine looks nothing like this.

If anything, modern qualified immunity does the opposite of what it ought to under the Frankfurter position. As discussed in Part I.A., qualified immunity comes closer to tracking state common law than it does to filling in state law's gaps. Frequently, an official who acts egregiously and in bad faith is potentially liable under both state tort law and constitutional doctrine; an official who acts mistakenly but in good faith will be liable under neither one.

To be sure, the power of this criticism depends a lot on how brutal a compensating adjustment is allowed to be. ${ }^{133}$ If one looks with a wide enough lens, one might say that it's enough that the first decision erroneously expanded the number of lawsuits and the second decision will decrease the number of lawsuits.

But this isn't and shouldn't be a well-accepted theory of compensating adjustments. First, with the lens that wide nearly every doctrine of constitutional law and civil procedure would be swept in. The theory would not provide special justification for the doctrine of qualified immunity. Second, to the extent that the original scheme had an animating purpose or logic, one would expect the adjustment to be consistent with that purpose. For instance, it would be a far closer approximation to the Frankfurterian scheme to require

132. See Marbury v. Madison, 5 U.S. (1 Cranch) 137, 147 (1803); see also Sina Kian, The Path of the Constitution: The Original System of Remedies, How It Changed, and How the Court Responded, 87 N.Y.U. L. REV. 132, 184 (2012) (providing a similar reading of Frankfurter's position). This view still leaves a gap when the state has no remedy for illegal conduct for non-officer-related reasons, such as the running of a statute of limitations. Of course, one might hope that tying together the rules for officials and regular people strongly limits a state's incentive to manipulate those procedural rules in nefarious ways. Cf. William Baude \& James Y. Stern, The Positive Law Model of the Fourth Amendment, 129 HARV. L. REV. 1821 (2016).

133. I owe this objection to Richard Re. 
that Section 1983 claims be exhausted ${ }^{134}$ or to substantively alter the doctrine for certain kinds of constitutional claims (like excessive force claims, perhaps). ${ }^{135}$ For sophisticated proponents of compensating adjustments, there are plenty of hard questions about how to choose among possible compensating adjustments. ${ }^{136}$ But for present purposes, it is enough to say that only an extremely crude theory could justify the Court's current qualified immunity jurisprudence. ${ }^{137}$

\section{The Lenity Theory}

\section{The Court's Account}

That leaves us with the oldest of the Court's justifications for qualified immunity, one based in lenity. It derives from cases that read a related enforcement provision in light of the need for fair warning, and later extended similar principles to Section 1983.

Section 1983 is not the only Reconstruction-era statute that enforces constitutional rights against state officials. In addition to the civil rights suits authorized by Section 1983, Congress passed a criminal prohibition toobeginning with the 1866 Civil Rights Act, and then modified to include the language of the $\mathrm{Ku}$ Klux Act. ${ }^{138}$ Now codified at 18 U.S.C. $\S 242$, the prohibition provides:

Whoever, under color of any law, statute, ordinance, regulation, or custom, willfully subjects any person in any State, Territory, Commonwealth, Possession, or District to the deprivation of any rights, privileges, or immunities secured or protected by the Constitution or laws of the United States, or to different punishments, pains, or penalties, on account of such person being an alien, or by reason of his color, or race, than are prescribed for the punishment of

134. Cf. Patsy v. Bd. of Regents of Fla., 457 U.S. 496, 533 (1982) (Powell, J., dissenting) (proposing exhaustion requirement, in part, to handle consequences of Monroe v. Pape).

135. Cf. Wurman, supra note 121 (proposing overhaul of qualified immunity and excessive force doctrine).

136. Vermeule, supra note 96, at 433-34 (footnotes omitted) (“A standard conceptual objection is that the policy of adjustment is indeterminate, as the interpreter may choose the margin on which the adjustment is made. If sweeping delegations produce excessive presidential power, why adjust by upholding the legislative veto, as opposed to, say, granting Congress the commander-in-chief power?").

137. Id. at 434 ("Here as elsewhere in constitutional interpretation, however, the indeterminacy point is only partly persuasive; there are easy cases for second-best constitutionalism as well as for first-best interpretive theories. If the growth of omnibus legislation has undermined the veto power, we need no elaborate theoretical apparatus to appreciate that permitting the (otherwise suspect) line-item veto is a more fitting compensating adjustment than, say, making the veto immune from congressional override.").

138. See Screws v. United States, 325 U.S. 91, 99-100 (1945), and United States v. Lanier, 520 U.S. 259, 264 n.1 (1997), for the statutory history. 
citizens, shall be fined under this title or imprisoned . . . ${ }^{139}$

That provision does not contain any written defenses, aside from what can be read into the requirement of a "willful" mens rea. But once again, that does not mean that no defenses exist.

Criminal prosecution under this statute can raise a genuine problem of notice. The statute criminalizes a violation of constitutional rights, and everybody can easily read the Constitution for themselves. But as John Marshall reminded us, the Constitution does not "partake of the prolixity of a legal code." ${ }^{140}$ So simply reading the Constitution does not always tell an official much about what conduct the law forbids.

The fair notice problem is mitigated as we let judges expound and clarify the legal meaning of the Constitution's terms. Yet since the interpretations can change and are subject to contestation, a rule of narrow construction provides some leeway to those who could not fairly anticipate a change in judicial doctrine.

These principles animated the Court's early decision in United States $v$. Screws. ${ }^{141}$ There, the Court reviewed the conviction of three Georgia officials who were prosecuted under the contemporary version of Section 242 for beating a handcuffed man to death. Two of the Justices were inclined to affirm the convictions. ${ }^{142}$ Three others thought a federal conviction was not legally possible. ${ }^{143}$ That left Justice Douglas writing the plurality, and likely controlling, opinion. The statute might be unconstitutional, the plurality conceded, if it were read to broadly criminalize any violation of "a large body of changing and uncertain law," especially under the Due Process Clause. ${ }^{144}$ But the statute could be "confined more narrowly" and therefore withstood the charge of vagueness. ${ }^{145}$

That narrower interpretation had two parts. First the statute required a "willful" act, which could be interpreted "as connoting a purpose to deprive a person of a specific constitutional right." 146 But that alone did not solve the problem if "neither a law enforcement official nor a trial judge can know with sufficient definiteness the range of rights that are constitutional." ${ }^{\text {"47 }}$ So the specific intent had to be still more specific: to refer not just to constitutional rights but to rights made "definite by decision or other rule of law." 148 The

139. 18 U.S.C. $\S 242(2012)$.

140. McCulloch v. Maryland, 17 U.S. (4 Wheat.) 316, 407 (1819).

141. Screws, 325 U.S. at 91.

142. Id. at 134 (1945) (Rutledge, J., concurring); id. at 138 (Murphy, J., dissenting).

143. Id. at 139 (Roberts, J., dissenting, with Frankfurter \& Jackson, JJ.) (asserting a different interpretation of "under color of" state law, cf. supra Part I.B, and arguing that a contrary view was potentially unconstitutional).

144. Id. at 95-98.

145. Id. at 100.

146. Id. at 101.

147. Id. at 104.

148. Id. at 103. 
opinion repeated the formulation in various ways and said it would target somebody who "acts in defiance of announced rules of law" and "knows precisely what he is doing." 149

Because that new construction was inconsistent with the jury instructions, the plurality voted to remand for a new trial. That meant a three-way split on the proper disposition, with different Justices affirming, reversing with no new trial, or remanding with a new trial. To avoid a "stalemate," Justice Rutledge agreed to vote for a remand for a new trial under the plurality's opinion, rather than stick with his first choice to affirm. ${ }^{150}$ This likely turned the plurality's opinion into the controlling opinion, and it has since been adopted by the full Court. ${ }^{151}$

The exact character of the "fair warning"152 limiting construction was a little ambiguous. One might describe it as the rule of lenity favoring narrow construction of criminal statutes. One might instead describe it as a distinct rule that broad constructions of the criminal law cannot be applied retroactively. Or one might describe it as a rule that vague criminal statutes are unconstitutional, which the statute should be construed not to be. Indeed, the Court has since said that all three of those descriptions are "related manifestations of the fair warning requirement" applied to Section $242 .{ }^{153}$

These cases provide the final potential grounding for the doctrine of qualified immunity. The theory of lenity and fair warning imagines a state official as akin to a criminal defendant in need of special solicitude before being punished.

Modern qualified immunity doctrine does not usually mention the criminal rule of lenity, and one might have expected it to be limited to criminal cases. But in some opinions, the Court has equated the two. It has explicitly said that "[o]fficers sued in a civil action for damages under 42 U.S.C. $\S 1983$ have the same right to fair notice as do defendants charged with the criminal offense defined in 18 U.S.C. $§ 242 . " 154$ And in its most recent decision about the scope of criminal liability under Section 242, the Court has confirmed the connection, stating that "in effect the qualified immunity test is simply the adaptation of the fair warning standard to give officials ... the same protection

149. Id. at $104-05$.

150. Id. at 134 (Rutledge, J., concurring).

151. Williams v. United States, 341 U.S. 97, 100-02 (1951); see also United States v. Lanier, 520 U.S. 259, 267 (1997); United States v. Guest, 383 U.S. 745, 760 (1966); United States v. Price, 383 U.S. 787, 792-93 (1966).

152. Screws, 325 U.S. at 104.

153. Lanier, 520 U.S. at 266. To further complicate these manifestations, the nature of the socalled "rule of lenity" has changed over time. See John F. Stinneford, Dividing Crime, Multiplying Punishments, 48 U.C. DAVIS L. REV. 1955, 1995 (2015) (footnotes omitted) ("Prior to the 1950s, the rule of lenity was called the rule of strict construction of penal statutes. This rule was not primarily about notice or separation of powers; nor was it about giving criminals undeserved 'lenience."').

154. Hope v. Pelzer, 536 U.S. 730, 739 (2002). 
from civil liability and its consequences that individuals have traditionally possessed in the face of vague criminal statutes." 155

To be sure, there is something counterintuitive about supposing that constitutional law itself can be unconstitutionally vague, or that government officials, of all people, need not know it. ${ }^{156}$ But once one is looking for it, the lenity connection may also explain some of the Court's elaborations of the qualified immunity standard. For instance, when the Court says that only "the plainly incompetent or those who knowingly violate the law" can be held liable,${ }^{157}$ it seems to be adverting to criminal recklessness or deliberate wrongdoing. When the Court says that the Fourth Amendment is not enough to clearly establish the unreasonableness of most violations of the Fourth Amendment, ${ }^{158}$ it seems to be adverting to the problem of criminal vagueness in light of the fact that the Constitution is not written out as a legal code. Qualified immunity seems to rest on an intuition that officials are not to blame for reasonable mistakes.

But does this justification actually support modern immunity doctrine? Some of its premises are legally sound: criminal prohibitions should be read in light of longstanding legal and interpretive principles, and constitutional avoidance and lenity are such principles. And yet...

\section{The Civil/Criminal Problem}

One could fairly have more misgivings about importing the limited construction of the criminal statute to the civil one.

To be sure, the Court has sometimes applied the canonically criminal "rule of lenity" in civil cases, if the same language has parallel application in a criminal case. For instance, the Court in U.S. v. Thompson/Center Arms Co. confronted "a tax statute that we construe now in a civil setting" but applied the rule of lenity because the statute also had "criminal applications." 159 This rule tracked some language in previous tax cases. ${ }^{160}$

The Court has since done the same thing when defining "aggravated felony" for purposes of the immigration laws, reasoning:

Although here we deal with [18 U.S.C.] $\S 16$ in the deportation context, $\S 16$ is a criminal statute, and it has both criminal and

155. Lanier, 520 U.S. at $270-71$.

156. But cf. Richard H. Fallon, Jr., Judicially Manageable Standards and Constitutional Meaning, 119 HARV. L. REV. 1275, 1323 (2006) (noting that "many background norms are too vague to permit application until they have been further specified").

157. Malley v. Briggs, 475 U.S. 335, 341 (1986), invoked most recently in Ziglar v. Abbasi, 137 S. Ct. 1843,1867 (2017).

158. Saucier v. Katz, 533 U.S. 194, 201-02 (2001); Anderson v. Creighton, 483 U.S. 635, $643-$ 44 (1987).

159. 504 U.S. 505, 517-18 (1992) (plurality opinion) (Souter, J.); see also id. at 519 (Scalia, J., concurring) (agreeing that the rule of lenity applied).

160. Crandon v. United States, 494 U.S. 152, 158 (1990). 
noncriminal applications. Because we must interpret the statute consistently, whether we encounter its application in a criminal or noncriminal context, the rule of lenity applies. ${ }^{161}$

However, this "civil" rule of lenity might not carry over to Section 1983. Unlike the statutes at issue in Leocal and Thompson, Section 1983 does not have criminal applications; it simply parallels the language of another statute that does, 18 U.S.C. $\S 242$. Thus, Section 1983 does not quite implicate the "unitary principle" that "a term occurring a single time in a single statutory provision should have a single meaning." "162

Moreover, there is also an important textual difference between the two civil rights provisions. Section 242 applies only to those who "willfully" violate constitutional rights, while Section 1983 contains no such limitation. In Thompson, the plurality hinted that this was a relevant distinction, pointing out that the tax statute at issue there "has criminal applications that carry no additional requirement of willfulness." 163

Indeed, the Court made a similar point about the two civil rights statutes in Monroe v. Pape, specifically noting:

In the Screws case we dealt with a statute that imposed criminal penalties for acts "willfully" done. We construed that word in its setting to mean the doing of an act with "a specific intent to deprive a person of a federal right." We do not think that gloss should be placed on [§ 1983] which we have here. The word "willfully" does not appear in [§ 1983.] Moreover, [ $\S 1983$ ] provides a civil remedy, while in the Screws case we dealt with a criminal law challenged on the ground of vagueness. Section [1983] should be read against the background of tort liability that makes a man responsible for the natural consequences of his actions. ${ }^{164}$

While this passage is somewhat opaque, it and Thompson cut against the application of the criminal rule of lenity to Section 1983.

We could also consider the related doctrine of constitutional fair warning. To the extent that the fair warning principle derives from the Constitution's Due Process Clause, due process is required both for deprivations of liberty (as in many criminal cases) and for deprivations of property (as in civil actions for damages). ${ }^{165}$

161. Leocal v. Ashcroft, 543 U.S. 1, 11 n.8 (2004).

162. Jonathan R. Siegel, The Polymorphic Principle and the Judicial Role in Statutory Interpretation, 84 TEX. L. REV. 339, 343 (2005) (describing, though not fully endorsing, this principle).

163. 504 U.S. at 517.

164. 365 U.S. 167, 187 (1961) (internal citations omitted).

165. Cf. Stinneford, supra note 153, at 2001 (arguing that the historical "rule of strict construction of penal statutes" was connected to the Due Process Clause's protection of life and liberty). 
However, criminal prosecutions have generally been thought to present distinct fair-warning concerns that do not apply to civil statutes. As the Court has put it: "The standards of certainty in statutes punishing for offenses is higher than in those depending primarily upon civil sanction for enforcement." ${ }^{166}$ However, a more recent case, FCC v. Fox, may have blurred that line because it applied criminal vagueness precedents in a civil case. ${ }^{167}$

Thus, it is possible that qualified immunity doctrine under Section 1983 could be justified on fair notice and lenity principles, but that would require some extension of the current version of those principles.

\section{The Mismatch Problem}

Even if we grant that Section 1983 falls within the domain of lenity and fair notice, there is a less lofty reason that those principles cannot justify qualified immunity doctrine: Qualified immunity doctrine has come to bear little practical resemblance to the rules applicable to criminal defendants.

Consider how the Court treats judicial disagreement in both the criminal and qualified-immunity contexts. Many cases in the Supreme Court have been subject to a "circuit split," meaning that the lower courts have disagreed. When judges disagree, that might be a clue that the legal question is hard and the materials are ambiguous. ${ }^{168}$ If the materials are ambiguous, that is reason to favor the criminal defendant or official. But the Court treats qualified immunity and the ordinary criminal defendant in almost the opposite fashion. ${ }^{169}$

Indeed, the Court has explicitly rejected the relevance of circuit splits to the lenity inquiry, stating that "we [have not] deemed a division of judicial authority automatically sufficient to trigger lenity." ${ }^{\prime 70}$ When faced with a defendant who asked for a fair notice defense because his circuit had established precedent construing a criminal statute more narrowly, the Court said no: reliance on this precedent was "unavailing since the existence of conflicting cases from other Courts of Appeals made review of that issue by

166. Winters v. New York, 333 U.S. 507, 515 (1948); Hoffman Estates v. Flipside, 455 U.S. 489, 498-99 (1982).

167. FCC v. Fox Television Stations, Inc., 567 U.S. 239, 253 (2012) (applying criminal vagueness precedents in a civil case); see also Theodore J. Boutrous, Jr. \& Blaine H. Evanson, The Enduring and Universal Principle of "Fair Notice," 86 S. CAL. L. REV. 193, 198 (2013) (asserting that Fox equated the two standards).

168. See Eric A. Posner \& Adrian Vermeule, The Votes of Other Judges, 105 GEO. L.J. 159 (2016). But see William Baude \& Ryan D. Doerfler, Arguing with Friends (U. Chi. Pub. Law Working Paper No. 630) (July 3, 2017 draft), https://ssrn.com/abstract=2985032 [https://perma.cc/7WL593MR] (arguing that this should depend on shared methodology).

169. For similar observations, see Barbara E. Armacost, Qualified Immunity: Ignorance Excused, 51 VAND. L. REV. 583, 585 (1998); David B. Owens, Comment, Fourth Amendment Remedial Equilibration: A Comment on Herring v. United States and Pearson v. Callahan, 62 STAN. L. REV. 563, 589 (2010).

170. Moskal v. United States, 498 U.S. 103, 108 (1990). 
this Court and decision against the position of the respondent reasonably foreseeable." $" 171$

People regularly go to jail over this issue. In the past few years, for instance, the Court has ruled for the government in at least seven substantive criminal law cases where a lower court had adopted the defendant's position. ${ }^{172}$ In none of those cases did it apply the rules of lenity or fair warning or suggest that the division was relevant. ${ }^{173}$

In Section 1983 cases, by contrast, a circuit split is considered a strong point in favor of the official. Indeed, those cases come close to establishing that a circuit split is a per se defense of the official's conduct in circuits where the issue was unsettled. In Wilson v. Layne, for instance, the Court concluded that police officers had violated the Fourth Amendment by inviting members of the press to tag along during a home search. ${ }^{174}$ But the Court also concluded that the officers were entitled to qualified immunity, noting that the question was "by no means open and shut" 175 and that the officers had reasonably relied on established policy. It closed with an invocation of the fair notice principle in light of judicial disagreement:

Between the time of the events of this case and today's decision, a split among the Federal Circuits in fact developed on the question whether media ride-alongs that enter homes subject the police to money damages. If judges thus disagree on a constitutional question, it is unfair to subject police to money damages for picking the losing side of the controversy. ${ }^{176}$

171. United States v. Rodgers, 466 U.S. 475, 484 (1984). For criticism of the rule, see Trevor W. Morrison, Fair Warning and the Retroactive Judicial Expansion of Federal Criminal Statutes, 74 S. CAL. L. REV. 455, 461 (2001).

172. See Voisine v. United States, 136 S. Ct. 2272 (2016) (rejecting view of United States v. Nobriga, 474 F. 3d 561 (9th Cir. 2006)); Ocasio v. United States, 136 S. Ct. 1423 (2016) (rejecting view of United States v. Brock, 501 F.3d 762 (6th Cir. 2007)); Lockhart v. United States, 136 S. Ct. 958 (2016) (rejecting view of United States v. Trogdon, 339 F.3d 620 (8th Cir. 2003), and also expressly rejecting application of lenity); Whitfield v. United States, 135 S. Ct. 785 (2015) (rejecting view of United States v. Marx, 485 F.2d 1179 (10th Cir. 1973)); Loughrin v. United States, 134 S. Ct. 2384, 2388 (2014) (rejecting view of United States v. Thomas, 315 F.3d 190, 197 (3rd Cir. 2002); United States v. Kenrick, 221 F.3d 19, 29 (1st Cir. 2000); and United States v. Jacobs, 117 F.3d 82, 92-93 (2d Cir. 1997)); United States v. Castleman, 134 S. Ct. 1405, 1409 (2014), rev'g 695 F.3d 582 (6th Cir. 2012); United States v. Apel, 134 S. Ct. 1144, 1146 (2014), vacating 676 F.3d 1202 (9th Cir. 2012).

173. Johnson v. United States, which invalidated the residual clause of the Armed Career Criminal Act as vague, is a rare case that mentions "numerous splits among the lower federal courts" as a point in the defendant's favor. $135 \mathrm{~S}$. Ct. 2551, 2560 (2015). But it is still a far cry from the kind of near-dispositive relevance they get in qualified immunity cases. Indeed, the Court wrote that " $[\mathrm{t}] \mathrm{he}$ most telling feature of the lower courts' decisions is not division about whether the residual clause covers this or that crime (even clear laws produce close cases); it is, rather, pervasive disagreement about the nature of the inquiry one is supposed to conduct and the kinds of factors one is supposed to consider." Id. (emphasis added).

174. 526 U.S. 603, 609-14 (1999).

175. Id. at 615 .

176. Id. at 618 (internal citations omitted). 
That passage turned out to be an important part of Wilson, which provided a shield for law enforcement officers to claim that judicial disagreement should give them immunity from constitutional tort. ${ }^{177}$

In Safford v. Redding, the Court again held that officials had committed a Fourth Amendment violation, albeit in the very different context of a strip search of a 13-year-old girl suspected of possessing Ibuprofen at school. ${ }^{178}$ The Court held, although guardedly, that qualified immunity nonetheless attached because of the state of judicial disagreement:

We would not suggest that entitlement to qualified immunity is the guaranteed product of disuniform views of the law in the other federal, or state, courts, and the fact that a single judge, or even a group of judges, disagrees about the contours of a right does not automatically render the law unclear if we have been clear. That said, however, the cases viewing school strip searches differently from the way we see them are numerous enough, with well-reasoned majority and dissenting opinions, to counsel doubt that we were sufficiently clear in the prior statement of law. ${ }^{179}$

The Court has continued to find immunity on the basis of judicial disagreement. For instance, it quoted Wilson again in Reichle v. Howards. ${ }^{180}$ It then held in Lane v. Franks that a defendant was entitled to qualified immunity even though other circuits had (correctly) held his conduct unconstitutional, because the defendant was allowed to ignore those decisions and rely on his own circuit's (erroneous) precedent. ${ }^{181}$ And most recently in Ziglar v. Abbasi, the Court granted federal officials qualified immunity from a claim of conspiracy to violate civil rights because of judicial disagreement about the definition of conspiracy, reasoning that " $[\mathrm{w}]$ hen the courts are divided on an issue so central to the cause of action alleged, a reasonable official lacks the notice required before imposing liability." 182

177. Cf. John P. Elwood, What Were They Thinking: The Supreme Court in Revue, October Term 2008, 12 GREEN BAG 2D 429, 441 (2009) (noting that passage was "much beloved by the SG's Office").

178. Safford Unified Sch. Dist. No. 1 v. Redding, 557 U.S. 364, 376-77 (2009). There was surprisingly pointed debate in the Ninth Circuit about whether the search was technically a "strip search." Compare Redding v. Safford Unified Sch. Dist. No. 1, 531 F.3d 1071, 1080-81 (en banc), with id. at 1091 n.1 (Hawkins, J., dissenting). The Court commented: "The exact label for this final step in the intrusion is not important, though strip search is a fair way to speak of it." 557 U.S.at 374.

179. Safford, 557 U.S. at 378-79.

180. Reichle v. Howards, 566 U.S. 658, 669-70 (2012); see also Pearson v. Callahan, 555 U.S. 223, 245 (2009).

181. 134 S. Ct. 2369,2383 (2014).

182. 137 S. Ct. 1843, 1868 (2017) (citing Wilson v. Layne, 526 U.S. 603, 618 (1999) and Reichle, 566 U.S. at 669-70). Ziglar was a suit under 42 U.S.C. $§ 1985$, originally enacted as a related part of the Ku Klux Act. Until Ziglar, there was a circuit split about whether qualified immunity applied to suits under Section 1985. Compare Burrell v. Bd. of Trs. of Ga. Military Coll., 970 F.2d 785, 794 (11th Cir. 1992), with Bisbee v. Bey, 39 F.3d 1096, 1102 (10th Cir. 1994); see also Petition for a Writ of Certiorari, Morgan v. Swint, 514 U.S. 1003 (1995) (No. 93-1638), cert. denied 514 U.S. 
In some other cases, the Court has hinted at going farther, suggesting that even where a circuit decision in the relevant circuit had clearly established that an action was unlawful, officials might still be justified in treating that opinion with skepticism until the Supreme Court has weighed in. ${ }^{183}$ While the Court has not (yet?) treated judicial disagreement as the source of a per se immunity, the difference between the Court's treatment of immunity analysis and of ordinary criminal cases is stark. Criminal defendants never get such solicitude.

If the only legal basis for qualified immunity doctrine is as an extension of the lenity and fair warning principles, then the doctrine needs to be radically overhauled. The Justices regularly empathize with officials subject to suit, asking if the official can really be expected to anticipate constitutional rulings that even federal appellate judges did not. But one rarely sees a similar empathy for regular criminal defendants, and indeed the Court's decisions do not bear it out. ${ }^{184}$

Thus the lenity theory, while in some respects the most obscure, might be the best path to some kind of immunity. But it seems to justify a much more modest immunity doctrine than the one we have, one that at most, tracks the modest defenses available to real criminal defendants.

\section{What Immunity Can Be Justified?}

\section{Justifying Qualified Immunity?}

Close inspection suggests that something has gone wrong, as a legal matter, in the Court's immunity doctrine. But it is not the case, as more extreme accounts have suggested, ${ }^{185}$ that Section 1983 permits absolutely no immunities at all because the text is categorical on its face. Unwritten defenses are not unknown to the law. The real problem with qualified immunity is that it is so far removed from ordinary principles of legal interpretation.

To be sure, this assessment of qualified immunity depends on how much freedom judges have in interpreting law. If one takes a very freewheeling view, one could decide that one of the Court's theories provides an adequate seed for some kind of immunity, and that such an immunity can then be reshaped at the Court's will, even in very dramatic ways. But I doubt that judges have such

1003 (1995). Ziglar held that it did, though the Court and the parties did not mention that it had been an open question.

183. See Carroll v. Carman, 135 S. Ct. 348, 350 (2014); see also Richard M. Re, Should Circuit Precedent Deprive Officers of Qualified Immunity?, RE's JuDICATA (Nov. 17, 2014, 6:49 AM), http://richardresjudicata.wordpress.com/2014/11/17/should-circuit-precedent-deprive-officersof-qualified-immunity [https://perma.cc/66K9-GY6L] (assessing Carroll).

184. One could instead solve the mismatch by giving all criminal defendants the equivalent of qualified immunity. Cf. Posner \& Vermeule, supra note 168, at 172-73.

185. See, e.g., Briscoe v. LaHue, 460 U.S. 325, 356-63 (1983) (Marshall, J., dissenting); Pierson v. Ray, 386 U.S. 547, 558-59 (1967) (Douglas, J., dissenting); Tenney v. Brandhove, 341 U.S. 367, 379 (1951) (Douglas, J., dissenting). 
broad power under the norms that are (mostly) observed by our legal system. ${ }^{186}$ In any event, if this is the way to justify qualified immunity, it emphasizes how much the immunity doctrine is a product of the Court's own choices and not ordinary posited law. Exposing the Court's choices lets us make a clearer and more responsible decision about whether those choices are the right ones or whether, having given us such a categorical immunity doctrine, the Court should now take some of it back.

Similarly, it is possible that the Court could put forward an entirely new legal argument for qualified immunity. Maybe Section 1983 could be reconceived as a common-law statute analogous to the Sherman Antitrust Act. ${ }^{187}$ Of that statute, the Court has concluded that Congress "expected the courts to give shape to the statute's broad mandate" 188 by "recognizing and adapting to changed circumstances and the lessons of accumulated experience." ${ }^{189}$ The Court has so far denied a similar kind of adapting role in creating immunities under Section 1983. ${ }^{190}$

An ambitious interpreter might also try to justify qualified immunity as an application of the absurdity doctrine, which rejects interpretations that "would produce an absurd and unjust result which Congress could not have intended." ${ }^{191}$ Even accepting the validity of the absurdity doctrine, ${ }^{192}$ it seems counterintuitive at best to say that Congress could not have intended a regime without qualified immunity, given the historical periods in which we got by without it. ${ }^{193}$ In any event, the Court has not attempted this path either.

Finally, the Court might attempt to justify immunity on purely functional grounds. Its cases already put forward some functional justifications for immunity, noting that it "free[s] officials from the concerns of litigation, including 'avoidance of disruptive discovery," "194 and responds to "the danger

186. Cf. Baude \& Sachs, supra note 5, at 1138-39.

187. Margaret H. Lemos, The Consequences of Congress's Choice of Delegate: Judicial and Agency Interpretations of Title VII, 63 VAND. L. REV. 363, 370-71, 379-80 (2010); Caleb Nelson, State and Federal Models of the Interaction Between Statutes and Unwritten Law, 80 U. CHI. L. REV. 657, 762-63 (2013).

188. Nat'l Soc'y of Prof'l Eng'rs v. United States, 435 U.S. 679, 688 (1978).

189. State Oil Co. v. Khan, 522 U.S. 3, 20 (1997); see also William N. Eskridge, Jr. \& John Ferejohn, Super-Statutes, 50 DUKE L.J. 1215, 1225-26, 1231-37 (2001) (describing the Sherman Act as a "super statute" and arguing that Section 1983 has become one as well). The relationship of "super statutes" to "common law statutes" is beyond the scope of this Article.

190. Malley v. Briggs, 475 U.S. 335, 342 (1986); Tower v. Glover, 467 U.S. 914, 922-23 (1984), both quoted supra notes 40-41.

191. Clinton v. City of New York, 524 U.S. 417, 429 (1998) (quoting Griffin v. Oceanic Contractors, Inc., 458 U.S. 564, 574 (1982)); see also Util. Air Regulatory Grp. v. EPA, 134 S. Ct. 2427, 2442-44 (2014).

192. Compare ANTONIN SCALIA \& BRYAN A. GARNER, READING LAW: THE INTERPRETATION OF Legal TeXts 234-39 (2012), with John F. Manning, The Absurdity Doctrine, 116 HARV. L. ReV. 2387 (2003).

193. See supra notes $46-66$ and accompanying text.

194. Ashcroft v. Iqbal, 556 U.S. 662, 685 (2009) (quoting Siegert v. Gilley, 500 U.S. 226, 236 (1991) (Kennedy, J., concurring)). 
that fear of being sued will 'dampen the ardor of all but the most resolute, or the most irresponsible [public officials], in the unflinching discharge of their duties." " 195 So far, though, the Court has used more traditional legal arguments as the opening wedge for these policy concerns. If the statute and its background principles do not authorize this immunity, the Court would have to assert a more freestanding justification.

What all of these hypothetical interpretive approaches have in common is that they would more explicitly foreground the live policy debates about whether qualified immunity is wise or useful and about how it interacts with other aspects of our legal regime such as indemnification, sovereign immunity, and doctrinal change. ${ }^{196}$ It is far from clear that qualified immunity would survive those debates unscathed. So perhaps qualified immunity doctrine can be made lawful, though I doubt it, and in any event that question ought to preoccupy us far more than it does.

\section{Justifying Other Immunities}

Finally, it may well be that some of the other immunities recognized by the Court's cases stand on substantially firmer footing. For instance, the Court's cases recognizing state sovereign immunity are basically correct (or at least, I have so argued). ${ }^{197}$

It is possible that some official immunities, such as the absolute immunity given to judges for their judicial acts, could also be justified. ${ }^{198}$ Cases decided nearly contemporaneously with Section 1983's enactment support judicial immunity. In 1869, the Court affirmed judicial immunity in a state disbarment suit, opining that "it is a general principle applicable to all judicial officers, that they are not liable to a civil action for any judicial act done within their jurisdiction. $" 199$ The Court reaffirmed that rule again in 1872, the year after Section 1983 was enacted. ${ }^{200}$ The rule evidenced by these cases might well support something like the doctrine of judicial immunity. These immunity cases do require some extrapolation; it has been argued that the legislative history of Section 1983 rejects absolute judicial immunity. ${ }^{201}$ But my analysis

195. Harlow v. Fitzgerald, 457 U.S. 800, 814 (1982) (quoting Gregoire v. Biddle, 177 F.2d 579, 581 (2d Cir. 1949)).

196. See supra notes 1-6.

197. See Baude, supra note 19.

198. Stump v. Sparkman, 435 U.S. 349, 364 (1978); Pierson v. Ray, 386 U.S. 547, 554 (1967).

199. Randall v. Brigham, 74 U.S. (7 Wall.) 523, 535 (1868).

200. Bradley v. Fisher, 80 U.S. (13 Wall.) 335, 355 (1871). Randall and Bradley are two of many nineteenth-century cases whose decision date is not accurately reflected in the U.S. Reports. See ANNE ASHMORE, Supreme COURT OF THE United StATES, DATES OF SUPREME COURT DECISIONS AND ARGUMENTS 93, 105, http://www.supremecourt.gov/opinions/datesofdecisions.pdf [https://perma.cc/K4FP-U9EF].

201. Note, Liability of Judicial Officers Under Section 1983, 79 YALE L.J. 322, 327-28 (1969); see also Pierson, 386 U.S. at 559 (Douglas, J., dissenting) ("The congressional purpose seems to me to be clear."). 
of qualified immunity does not necessarily imperil these other immunities, which might have their own firmer historical and legal bases.

II.

IMPLICATIONS

\section{A. Qualified Immunity Doctrine}

Suppose it is true that the Court's proffered justifications for qualified immunity are shaky and that it does not hold up under ordinary principles of statutory interpretation. What should actually happen to modern qualified immunity doctrine?

The most obvious possibility is that the Court could overrule or modify the doctrine. This possibility is obvious in the sense that it is straightforward, not in the sense that the Court is likely to do it. A doctrine's lack of a legal basis is a necessary condition for overturning it, but it is not a sufficient one.

Under orthodox rules of stare decisis, the Court might be extremely reluctant to overturn qualified immunity, even if it is wrong. The Court is generally extremely reluctant to overturn statutory precedents, ${ }^{202}$ and qualified immunity seems to be a largely statutory precedent. In statutory cases, the argument goes, Congress is fully capable of overruling precedent and is the better agent to do so. ${ }^{203}$ Because qualified immunity has been on the books for years and Congress has declined to revisit it, it may have obtained a belated Congressional imprimatur. ${ }^{204}$

But qualified immunity doctrine seems unorthodox in several respects. First, it is not entirely clear that the Court views qualified immunity as a purely statutory rule, as opposed to a constitutionally protected one. ${ }^{205}$ The lenity rationale for qualified immunity has some constitutional overtones, and the early arguments rejected in Myers $v$. Anderson invoked constitutional considerations. ${ }^{206}$ Apart from the lenity rationale, qualified immunity and other official immunities do generally appear to be common-law rules, and Congress

202. See, e.g., 14 Penn Plaza LLC v. Pyett, 556 U.S. 247, 280-81 (2009).

203. NELSON, supra note 13, at 426-29 (analyzing and questioning this rationale).

204. Additionally, during this time Congress has amended Section 1983 in another, albeit minor, respect dealing with injunctive relief against judges. See Federal Courts Improvement Act of 1996, Pub. L. No. 104-317, § 309, 110 Stat. 3847, 3853 (codified as amended at 28 U.S.C. § 1983 (2012)).

205. Compare Seth P. Waxman \& Trevor W. Morrison, What Kind of Immunity? Federal Officers, State Criminal Law, and the Supremacy Clause, 112 YALE L.J. 2195, 2209 (2003) ("It bears emphasizing that qualified immunity does not appear to be constitutionally required."), with RICHARD H. Fallon, JR., John F. Manning, Daniel J. Meltzer \& David L. Shapiro, Hart and WeChSler's The Federal COURTS AND THE Federal System 1041 (7th ed. 2015) ("Could Congress narrow or abolish immunities in $\S 1983$ actions?").

206. Supplemental Brief for Plaintiffs in Error, Myers v. Anderson, supra note 63. 
normally can change the common law. ${ }^{207}$ But one might have anticipated the same thing about sovereign immunity, which the Court held Congress is largely powerless to abrogate. ${ }^{208}$ And when the Court held that legislative immunity survived Section 1983, it said it was willing to "assume, merely for the moment, that Congress has constitutional power to limit the freedom of State legislators acting within their traditional sphere." But, it added, "[t]hat would be a big assumption." 209

Despite these constitutional shadows, one can and probably should distinguish qualified immunity from these other immunities. Nevertheless, they are enough to show a path by which the Court might say that qualified immunity is not a purely statutory doctrine left to the pleasure of Congress. Indeed, Felix Frankfurter argued that reconsidering the interpretation of Section 1983 was "the Court's responsibility" because it was not "merely a mine-run statutory question," but rather one that "has significance approximating constitutional dimension." 210

Second, even while qualified immunity has remained in place, the Court has openly tinkered with it to an unusual degree. It explicitly eliminated the subjective component of immunity in Harlow v. Fitzgerald, focusing the inquiry instead on "clearly established law." "It It created a special sequencing requirement in Saucier v. Katz ${ }^{212}$ and then replaced it with a new set of principles in Pearson v. Callahan. ${ }^{213}$ These points may not show that qualified immunity is fundamentally unstable, but they suggest that the Court takes more ownership of it than more orthodox statutory doctrines.

Even if the Court refuses to overrule qualified immunity, it might tinker with the doctrine more incrementally. Some suggest that this has already happened, arguing that after Harlow the Court reformulated the qualified

207. Once again, see supra note 99 , I bracket the possibility that there are distinct limits on Congress's power to regulate the qualified immunity of federal officials. See William Baude, Sharing the Necessary and Proper Clause, 128 HARV. L. REV. F. 39, 46-47 (2014).

208. See Seminole Tribe of Fla. v. Florida, 517 U.S. 44, 88 (1996) (Stevens, J., dissenting) ("There is no reason why Congress' undoubted power to displace those common-law immunities [such as qualified immunity] should be either greater or lesser than its power to displace the commonlaw sovereign immunity defense."). On Congress's power to abrogate sovereign immunity, see Baude, supra note 19 , at $12-22$.

209. Tenney v. Brandhove, 341 U.S. 367, 376 (1951).

210. Monroe v. Pape, 365 U.S. 167, 221-22 (1961) (Frankfurter, J., dissenting); cf. Monell v. Dep't of Soc. Servs, 436 U.S. 658, 695 (1978) (overruling prior precedent interpreting Section 1983 notwithstanding statutory stare decisis principle). This conclusion would be amplified if one concluded that Section 1983 is a "common law statute," because "the Supreme Court has indicated that the traditionally 'super strong' stare decisis applied to statutory decisions will be relaxed - and perhaps even abandoned" for such statutes. Lemos, supra note 187, at 379-80.

211. 457 U.S. 800, 818-19 (1982).

212. 533 U.S. 194 (2001).

213. 555 U.S. 223 (2009). 
immunity to subtly strengthen it, ${ }^{214}$ or that the Roberts Court is now doing the same thing. ${ }^{215}$ The Court could cut back on some of the excesses of qualified immunity in similar fashion. As Richard Re has pointed out, when a line of doctrine points in a problematic direction, it is highly traditional to "narrow" it, ${ }^{216}$ leaving its roots intact while refusing to allow new branches to take their natural course. Justice Kennedy has suggested such an approach in the qualified immunity context. ${ }^{217}$

\section{B. The Qualified Immunity Docket}

Setting aside formal and informal tinkering with the doctrinal formula of qualified immunity, ${ }^{218}$ there is another important aspect of qualified immunity that might call for reconsideration: the Supreme Court's special treatment of qualified immunity issues on its certiorari docket. There are two aspects to that special treatment, both of which seem to be getting more special in recent years.

First, nearly all of the Supreme Court's qualified immunity cases come out the same way - by finding immunity for the officials. In the thirty-five years since it announced the objective-reasonableness standard in Harlow $v$. Fitzgerald, the Court has applied it in thirty qualified immunity cases. ${ }^{219}$ Only twice has the Court actually found official conduct to violate clearly established law. Those two findings, in Groh v. Ramirez and Hope v. Pelzer, occurred more than a decade ago. The former relied on a glaring mistake in a

214. Kathryn R. Urbonya, Problematic Standards of Reasonableness: Qualified Immunity in Section 1983 Actions for a Police Officer's Use of Excessive Force, 62 TEMP. L. REV. 61, 81 (1989) (discussing Malley v. Briggs, 475 U.S. 335 (1986) and Anderson v. Creighton, 483 U.S. 635 (1987)).

215. Karlan, supra note 116, at 61-62; Stephen R. Reinhardt, The Demise of Habeas Corpus and The Rise of Qualified Immunity: The Court's Ever Increasing Limitations on the Development and Enforcement of Constitutional Rights and Some Particularly Unfortunate Consequences, $113 \mathrm{MICH}$. L. REV. 1219, 1248 (2015) (discussing Ashcroft v. al-Kidd, 563 U.S. 731 (2011)).

216. Richard M. Re, Narrowing Precedent in the Supreme Court, 114 COLUM. L. REV. 1861 (2014)

217. Wyatt v. Cole, 504 U.S. 158, 171 (1992) (Kennedy, J., concurring) ("We need not decide whether or not it was appropriate for the Court in Harlow to depart from history in the name of public policy, reshaping immunity doctrines in light of those policy considerations. But I would not extend that approach to other contexts.").

218. Cf. Fallon, supra note 6, at 494 (claiming "that formula has remained relatively untouched in recent decades").

219. See Appendix. For simplicity, the appendix omits some additional cases concerning qualified immunity that were decided only on procedural grounds and without application of the clearly established standard. See, e.g., Tolan v. Cotton, 134 S. Ct. 1861, 1868 (2014) (reversing because of "a clear misapprehension of summary judgment standards" and declining to "express a view as to whether Cotton's actions violated clearly established law"); Behrens v. Pelletier, 516 U.S. 299, 313 (1996) (finding a right to interlocutory appeal but leaving the lower court the task of determining whether the summary judgment evidence "met the Harlow standard of 'objective legal reasonableness"'). 
search warrant; ${ }^{220}$ the latter involved the use of a hitching post for prison discipline in violation of longstanding circuit precedent. ${ }^{221}$

Only two other qualified immunity cases could be counted as partial victories for the plaintiffs under the objective-reasonableness standard. In 2017 in Hernandez v. Mesa, the Court reversed an award of qualified immunity because the Fifth Circuit had looked at the facts from the wrong vantage point, but remanded without deciding whether the officer's conduct violated clearly established law under the correct vantage point. ${ }^{222}$ The other, Malley v. Briggs, dates back to 1986, and ordered a remand after rejecting, inter alia, an officer's argument that so long as he does not lie, "the act of applying for a warrant is per se objectively reasonable." ${ }^{223}$ Neither Hernandez nor Malley went so far as to actually find a violation of clearly established law.

This asymmetry may have an important effect on how qualified immunity operates. The Court regularly reminds lower courts that "clearly established law" has to be understood concretely. It is not enough to say that the Fourth Amendment is clearly established and therefore all Fourth Amendment violations are contrary to clearly established law. ${ }^{224}$ Nor is it enough to say, more specifically, that case law clearly establishes that the excessive use of force in making an arrest is unconstitutional and therefore all excessive force violations are clearly-established-law violations. ${ }^{225}$ The more general the relevant precedents, the more obvious the violation needs to be..$^{226}$

This framework makes it hard to find a roadmap to the denial of immunity that could give a lower court confidence in its conclusion. Because the Court's maps have nearly all been leading in the other direction, it becomes harder for lower courts to recognize a violation of clearly established law.

On top of that, because lower courts are somewhat regularly reversed for erring on the side of liability, but almost never reversed for erring on the side of immunity, the current docket signals to lower courts that they should drift toward immunity. My tally of immunity cases, if anything, understates the strength of that signal by omitting the many other cases where the Court found an official's conduct affirmatively lawful, thereby mooting the need to reach immunity. 227

220. Groh v. Ramirez, 540 U.S. 551, 564 (2004).

221. Hope v. Pelzer, 536 U.S. 730, 741-42 (2002).

222. 137 S. Ct. 2003, 2007 (2017).

223. 475 U.S. 335,345 (1986). It is not clear that this case should even count, since the Court stressed that "[t]he question is not presented to us, nor do we decide, whether petitioner's conduct in this case was in fact objectively reasonable." Id. at $345 \mathrm{n} .8$. The case was never appealed after remand.

224. Anderson v. Creighton, 483 U.S. 635, 643-44 (1987).

225. Saucier v. Katz, 533 U.S. 194, 202 (2001).

226. Plumhoff v. Rickard, 134 S. Ct. 2012, 2023 (2014); Ashcroft v. al-Kidd, 563 U.S. 731, 741-42 (2011); see also White v. Pauly, 137 S. Ct. 548, 552 (2017).

227. See, e.g., Los Angeles v. Rettele, 550 U.S. 609 (2007) (per curiam). 
Moreover, the signal sent by these results is not accidental. The Court's decision to grant certiorari in these cases almost always previews the merits: all but two of the Court's awards of qualified immunity reversed the lower court's denial of immunity below. ${ }^{228}$ In other words, lower courts that follow Supreme Court doctrine should get the message: think twice before allowing a government official to be sued for unconstitutional conduct.

Second, a series of Supreme Court decisions have also given qualified immunity special status as a matter of civil procedure. An official is entitled to consideration of a motion to dismiss before any discovery, contrary to a district court's normal discretion to decide the timing of discovery and a motion to dismiss. ${ }^{229}$ An official is also entitled to an immediate appeal of the denial of that motion to dismiss, contrary to the normal rule that such denials are not appealable. ${ }^{230}$ Finally, an official is entitled to a second immediate appeal if his motion for summary judgment on the basis of qualified immunity is likewise denied. ${ }^{231}$

These latter two rules stem from the so-called collateral order doctrine established in 1949 by Cohen v. Beneficial Industry Loan. ${ }^{232}$ More recently, the Court suggested that the collateral order doctrine should not be extended ${ }^{233}$ and admitted that the doctrine "may have expanded beyond the limits dictated by its internal logic." ${ }^{234}$ Still, the Court has noted "the applicability of the doctrine in the context of qualified-immunity claims is well established." 235 And it has found time for a number of decisions about the scope of these interlocutory appeal rights. ${ }^{236}$

Third, and finally, qualified immunity cases receive special privilege in the certiorari process.

The Supreme Court decides five to six cases every year in a special fashion called summary reversal. Unlike the sixty to eighty "merits cases" that

228. The two are Lane v. Franks, 134 S. Ct. 2369 (2014), which affirmed the Eleventh Circuit's grant of qualified immunity, 523 Fed. Appx. 709 (2013), and Wilson v. Layne, 526 U.S. 603 (1999), which affirmed the en banc Fourth Circuit, 141 F.3d 111 (1998).

229. Mitchell v. Forsyth, 472 U.S. 511, 526 (1985); Harlow v. Fitzgerald, 457 U.S. 800, $817-$ 18 (1982); see also Edward A. Hartnett, Taming Twombly, Even After Iqbal, 158 U. PA. L. REv. 473, 507-12 (2010) (noting that outside of qualified immunity case, district court may permit some discovery while deferring ruling on motion to dismiss); Edward A. Hartnett, Taming Twombly: An Update After Matrixx, 75 LAW \& CONTEMP. PROBS., 37, 48-50 (2012) (same).

230. Mitchell, 472 U.S. at 524-30.

231. Behrens v. Pelletier, 516 U.S. 299, 311 (1996).

232. 337 U.S. 541, 546 (1949).

233. See Mohawk Indus., Inc. v. Carpenter, 558 U.S. 100, 113-14 (2009).

234. Ashcroft v. Iqbal, 556 U.S. 662, 672 (2009).

235. Id.

236. See Johnson v. Jones, 515 U.S. 304, 313 (1995) (no interlocutory appeal of "a question of 'evidence sufficiency"'); Scott v. Harris, 550 U.S. 372, 376 (2007) (ignoring Johnson); Plumhoff v. Rickard, 134 S. Ct. 2012, 2019 (2014) (narrowing Johnson); see also Tobias Barrington Wolff, Scott v. Harris and the Future of Summary Judgment, 15 NEV. L.J. 1351, 1368-75 (2015) (criticizing Plumhoff's expansion of the right to interlocutory appeal). 
are decided after extensive briefing and oral argument, the summary reversal cases are decided solely on the basis of the lower court proceeding and the certiorari papers. In essence, this requires the lower court decision to be so obviously wrong that the Court can rush to judgment, and sufficiently important that it is worth the Court's scarce attention despite the usual rule against "error correction.",237

In a 2015 article on what I called the Court's "shadow docket," I attempted to count which categories of errors had been targeted for repeated attention by the Court's summary reversal docket. The five seemingly special categories were: (1) refusals to uphold arbitration agreements, (2) failures to give district courts sentencing discretion under Booker, (3) grants of habeas corpus relief despite AEDPA, (4) grants of habeas relief where AEDPA was irrelevant, and (5) liability under Section 1983. ${ }^{238}$

The ad hoc threshold for those "special" categories was at least three cases, approximating 5 percent of the summary reversal docket. ${ }^{239}$ At the time, it was not clear if qualified immunity made the list because only two of the three summary reversals of Section 1983 liability involved immunity. In the time since The Shadow Docket was published, however, it has become clear that qualified immunity is special. The Court has since added four more qualified-immunity summary reversals, bringing the total above any nonhabeas category. ${ }^{240}$ After one of those summary reversals, the Court also summarily remanded, or "GVRed," three other qualified immunity cases for reconsideration in light of the summary reversal, hinting that their analysis was wrong and creating a multiplier effect. ${ }^{241}$

All of this is unusual. The Court's normal criteria for certiorari favor cases in which there is a split between lower courts or an important legal error. And the Court has specifically noted that fact-bound applications of existing law are generally unlikely to qualify as important enough for certiorari. ${ }^{242}$ But most of the Court's qualified immunity decisions are just fact-bound applications of the already-established principle that liability requires clearly established law. So only a special dispensation from the normal principles of certiorari explains the Court's qualified immunity docket.

237. See generally William Baude, Foreword: The Supreme Court's Shadow Docket, 9 N.Y.U. J.L. \& LIBERTY 1, 25-30, 38-40 (2015); see also SUP. CT. R. 10.

238. Baude, supra note 237, at 32 .

239. Id.

240. White v. Pauly, 137 S. Ct. 548 (2017); Mullenix v. Luna, 136 S. Ct. 305 (2015); Taylor v. Barkes, 135 S. Ct. 2042 (2015); Carroll v. Carman, 135 S. Ct. 348 (2014).

241. See Hunter v. Cole, 137 S. Ct. 497 (2016); Piper v. Middaugh, 136 S. Ct. 2408 (2016); Pickens v. Aldaba, 136 S. Ct. 479 (2015).

242. SUP. CT. R. 10 ("A petition for a writ of certiorari is rarely granted when the asserted error consists of erroneous factual findings or the misapplication of a properly stated rule of law."); see also Izumi Seimitsu Kogyo Kabushiki Kaisha v. U.S. Philips Corp., 510 U.S. 27, 34 (1993); Packwood v. Senate Select Comm. on Ethics, 510 U.S. 1319, 1320-21 (1994) (Rehnquist, C.J. as Circuit Justice); Cash v. Maxwell, 565 U.S. 1138, 1141 (2012) (Sotomayor, J., respecting the denial of certiorari). 
Indeed, the Court has now explicitly acknowledged that qualified immunity has such a privileged status. In the 2015 case of San Francisco $v$. Sheehan, police officers successfully petitioned for certiorari after the Ninth Circuit held that their conduct during an arrest violated both the Americans with Disabilities Act and clearly established law under the Fourth Amendment. It was the former question that had split the circuits, but the officers backtracked and refused to challenge the most controversial part of the Ninth Circuit's holding. ${ }^{243}$ The Court therefore dismissed that part of the case as improvidently granted. Curiously, however, it did not dismiss the other question about qualified immunity, even though there was no more of a circuit split implicated by that question. This prompted Justices Scalia and Kagan to dissent, arguing that the qualified immunity question would not have merited certiorari on its own and therefore there was no reason to keep it around. ${ }^{244}$

This dissent in turn provoked a footnote from the majority, which said that '[b]ecause of the importance of qualified immunity 'to society as a whole,' the Court often corrects lower courts when they wrongly subject individual officers to liability." ${ }^{245}$ This new justification for certiorari might suggest an even bigger rise in the Court's immunity-protection docket.

The Court's enthusiasm for qualified immunity does not seem to be flagging. Two weeks after Sheehan, the Court granted certiorari and summarily reversed another denial of qualified immunity with no dissent noted. ${ }^{246}$ In November 2015, it summarily reversed another over Justice Sotomayor's dissent. ${ }^{247}$ In January 2017, the Court summarily reversed yet another denial of qualified immunity, noting that it had "issued a number of opinions reversing federal courts in qualified immunity cases" 248 and that it had "found this necessary both because qualified immunity is important to 'society as a whole," ${ }^{249}$ and "because as an 'immunity from suit,' qualified immunity 'is effectively lost if a case is erroneously permitted to go to trial.",250 Justice Ginsburg wrote a concurring opinion. ${ }^{251}$ It is not clear that there is a consistent dissenter from the immunity-protection program. ${ }^{252}$

243. 135 S. Ct. $1765,1772-74(2015)$.

244. Id. at 1779 (Scalia, J. dissenting).

245. Id. at 1774 n.3 (internal citations omitted) (quoting Harlow v. Fitzgerald, 457 U. S. 800, 814 (1982)) (citing Carroll v. Carman, 135 S. Ct. 348 (2014); Wood v. Moss, 134 S. Ct. 2056 (2014); Plumhoff v. Rickard, 134 S. Ct. 2012 (2014); Stanton v. Sims, 134 S. Ct. 3 (2013); Reichle v. Howards, 566 U.S. 658 (2012)).

246. Taylor v. Barkes, 135 S. Ct. 2042 (2015). It is not clear whether the vote was in fact unanimous, or whether the dissenters simply chose not to publish their views. See Baude, supra note 237 , at $18-19$.

247. Mullenix v. Luna, 136 S. Ct. 305 (2015).

248. White v. Pauly, 137 S. Ct. 548, 551 (2017).

249. Id. (quoting Sheehan, 135 S. Ct. at 1774 n.3).

250. Id. (quoting Pearson v. Callahan, 555 U.S. 223, 231 (2009)).

251. White v. Pauly, 137 S. Ct. 548, 553 (2017) (Ginsburg, J., concurring) (noting that "the Court, as I comprehend its opinion, leaves open the propriety of denying summary judgment based on fact disputes over when Officer White arrived at the scene, what he may have witnessed, and whether 
These developments can be criticized on their own terms. For instance, even if it is true that "qualified immunity "is effectively lost if a case is erroneously permitted to go to trial, $", 253$ that is equally true of every defense appealable under the collateral order doctrine, such as sovereign immunity ${ }^{254}$ and criminal double jeopardy ${ }^{255}$ But those defenses are not given the same pride of place on the Court's docket. When the court originally described immunity as important "to society as a whole" in Harlow, ${ }^{256}$ it was simply making the point that the proper performance of public officials is of concern to the public. ${ }^{257}$ But that is true of nearly any alleged error in public law, and again it hardly follows that the fact-bound application of those doctrines deserves a special place on the Supreme Court's agenda. ${ }^{258}$

The legal flaws in the doctrine of qualified immunity cast an even more troubling light on this doctrinal activity. The Court is not just maintaining the doctrine of qualified immunity as a matter of precedent, but doubling down on it, enforcing it aggressively against lower courts. Indeed, its campaign to enforce qualified immunity in recent years has come to rival its campaign to enforce the restrictions on habeas relief, about which the Justices have been unusually explicit. ${ }^{259}$

But the restrictions on habeas relief come from AEDPA - a federal statute that was enacted by Congress and that is clear about the limitations on relief, such as the requirement that the erroneous decision "was contrary to, or involved an unreasonable application of, clearly established Federal law, as determined by the Supreme Court of the United States." 260 The Court's crusade to enforce those limits can be justified as service to the rule of law, to ensure that federal courts do not disregard a federal statute simply because they find its implications troubling.

he had adequate time to identify himself and order Samuel Pauly to drop his weapon before Officer White shot Pauly").

252. See Samuel R. Bagenstos, Who Is Responsible for the Stealth Assault on Civil Rights?, 114 Mich. L. REV. 893, 909 (2016) (reviewing SARAH STASZAK, NO DAY IN COURT: ACCESS TO JUSTICE AND THE POLITICS OF JUdiCiAl RETRENChMENT (2015)) ("Although the Court is not always unanimous on these issues, it is fair to say that qualified immunity has been as much a liberal as a conservative project on the Supreme Court.").

253. White, 137 S. Ct. at 551 (quoting Pearson, 555 U.S. at 231).

254. Puerto Rico Aqueduct \& Sewer Auth. v. Metcalf \& Eddy, Inc., 506 U.S. 139, 144 (1993).

255. Abney v. United States, 431 U.S. 651, 659 (1977).

256. Harlow v. Fitzgerald, 457 U.S. 800, 814 (1982). This proposition in Harlow is quoted in San Francisco v. Sheehan, 135 S. Ct. 1774 n.3 (2015) and in White, 137 S. Ct. at 551.

257. Harlow, 457 U.S. at 814 n.22 (citing Peter H. Schuck, Suing Our Servants: The Court, Congress, and the Liability of Public Officials for Damages, 1980 SuP. CT. REV. 281, 324-27 (1980)).

258. For the general point that the Court's agenda does not and need not track society's, see Frederick Schauer, Foreword: The Court's Agenda-and the Nation's, 120 HARV. L. REV. 4 (2006).

259. Baude, supra note 237, at 26-27, 31-32.

260. 28 U.S.C. $\S 2254(d)(1)(2012)$. 
The opposite is true of Section $1983:{ }^{261}$ that statute contains no explicit restrictions on monetary relief, and the restrictions imposed by qualified immunity have been wrongly imposed by the Court, not implied by the statute or the common law. The Court's crusade to enforce the doctrine of qualified immunity does not serve congressional intent or the rule of law. Instead, it exacerbates the very kind of legal mistake that its habeas agenda is designed to correct.

\section{CONCLUSION}

In suggesting that the doctrine of qualified immunity is unlawful, I do not mean to raise foundational questions about the American legal order or the basic notion of government under law. ${ }^{262}$ Rather, I mean the more modest point that the doctrine lacks legal justification, and the Court's justifications are unpersuasive.

Given the high stakes of government misconduct and the cynical cast of modern remedies scholarship, this inquiry may seem almost naive. But I submit that it is nonetheless of urgent importance. If qualified immunity leads to bad consequences, it can be fixed. But to fix it requires knowing who created it in the first place. If qualified immunity is unlawful, it can be overruled. And even if the Court does not overrule it, it can stop expanding the legal error.

APPENDIX: SUPREME COURT APPLICATIONS OF THE QUALIFIED IMMUNITY STANDARD FROM 1982 THROUGH 2017

\begin{tabular}{|l|l|l|l|}
\hline \multicolumn{1}{|c|}{ Case } & \multicolumn{1}{|c|}{ Official } & \multicolumn{1}{c|}{ Claim } & \multicolumn{1}{|c|}{$\begin{array}{c}\text { Lower } \\
\text { Court }\end{array}$} \\
\hline $\begin{array}{l}\text { Hernandez v. Mesa, 137 S. Ct. } \\
2003 \text { (2017) } * *\end{array}$ & $\begin{array}{l}\text { Federal Law Enforcement } \\
\text { (Border Patrol) }\end{array}$ & $\begin{array}{l}\text { Due Process } \\
\text { (Excessive Force) }\end{array}$ & 5th Cir. \\
\hline $\begin{array}{l}\text { Ziglar v. Abbasi, 137 S. Ct. } 1843 \\
(2017)\end{array}$ & $\begin{array}{l}\text { U.S. Attorney General. } \\
\text { other Department of } \\
\text { Justice Officials, and } \\
\text { Federal Corrections } \\
\text { Officials }\end{array}$ & Equal Protection & 2 Cir. \\
\hline $\begin{array}{l}\text { White v. Pauly, 137 S. Ct. } 548 \\
(2017)\end{array}$ & State Law Enforcement & $\begin{array}{l}\text { 4th Amdt. (Excessive } \\
\text { Force) }\end{array}$ & 10 th Cir. \\
\hline
\end{tabular}

261. Cf. Edward A. Hartnett, Summary Reversals in the Roberts Court, 38 CARDOZO L. REV. 591, 602 (2016) (footnote omitted) (quoting Parker v. Matthews, 567 U.S. 37, 40 (2012)) ("In the habeas cases, the Supreme Court is enforcing a Congressional statute that specifically refers to 'clearly established Federal law, as determined by the Supreme Court.' But the centralizing theme is also apparent in some of the qualified immunity cases, where Congress has not done anything of the sort.").

262. Compare Philip Hamburger, Is Administrative Law Unlawful? (2014), with Adrian Vermeule, No, 93 TEX. L. ReV. 1547 (2015) (reviewing Phillip Hamburger, IS ADMINISTRATIVE LAW UNLAWFUL? (2014)). 


\begin{tabular}{|c|c|c|c|}
\hline $\begin{array}{l}\text { Mullenix v. Luna, } 136 \text { S. Ct. } 305 \\
\text { (2015) }\end{array}$ & State Law Enforcement & $\begin{array}{l}\text { 4th Amdt. (Excessive } \\
\text { Force) }\end{array}$ & 5th Cir. \\
\hline $\begin{array}{l}\text { Taylor v. Barkes, } 135 \text { S. Ct. } \\
2042 \text { (2015) }\end{array}$ & State Corrections Officials & 8th Amdt. & 3d Cir. \\
\hline $\begin{array}{l}\text { San Francisco v. Sheehan, } 135 \mathrm{~S} . \\
\text { Ct. } 1765 \text { (2015) }\end{array}$ & Local Law Enforcement & $\begin{array}{l}\text { 4th Amdt. (Excessive } \\
\text { Force) }\end{array}$ & 9th Cir. \\
\hline $\begin{array}{l}\text { Carroll v. Carman, } 135 \text { S. Ct. } \\
348 \text { (2014) }\end{array}$ & State Law Enforcement & $\begin{array}{l}\text { 4th Amdt. (Illegal } \\
\text { Entry) }\end{array}$ & 3d Cir. \\
\hline $\begin{array}{l}\text { Lane v. Franks, } 134 \text { S. Ct. } 2369 \\
\text { (2014) }\end{array}$ & $\begin{array}{l}\text { Community College } \\
\text { President }\end{array}$ & $\begin{array}{l}\text { 1st Amdt. } \\
\text { (Employment) }\end{array}$ & $\begin{array}{l}11 \text { th Cir. } \\
*\end{array}$ \\
\hline $\begin{array}{l}\text { Plumhoff v. Rickard, } 134 \text { S. Ct. } \\
2012 \text { (2014) }\end{array}$ & Local Law Enforcement & $\begin{array}{l}\text { 4th Amdt. (Excessive } \\
\text { Force) }\end{array}$ & 6th Cir. \\
\hline $\begin{array}{l}\text { Wood v. Moss, } 134 \text { S. Ct. } 2056 \\
\text { (2014) }\end{array}$ & Secret Service & $\begin{array}{l}\text { 1st Amdt. } \\
\text { (Assembly) }\end{array}$ & 9th Cir. \\
\hline $\begin{array}{l}\text { Stanton v. Sims, } 134 \text { S. Ct. } 3 \\
\text { (2013) }\end{array}$ & Local Law Enforcement & $\begin{array}{l}\text { 4th Amdt. (Illegal } \\
\text { Entry) }\end{array}$ & 9th Cir. \\
\hline $\begin{array}{l}\text { Reichle v. Howards, } 566 \text { U.S. } \\
658 \text { (2012) }\end{array}$ & Secret Service & $\begin{array}{l}\text { 1st Amdt. } \\
\text { (Retaliation) }\end{array}$ & 10th Cir. \\
\hline $\begin{array}{l}\text { Filarsky v. Delia, } 566 \text { U.S. } 377 \\
\text { (2012) }\end{array}$ & City Outside Counsel & Due Process & 9th Cir. \\
\hline $\begin{array}{l}\text { Messerschmidt v. Millender, } 565 \\
\text { U.S. } 535 \text { (2012) }\end{array}$ & County Law Enforcement & $\begin{array}{l}\text { 4th Amdt. } \\
\text { (Search/Seizure) }\end{array}$ & 9th Cir. \\
\hline $\begin{array}{l}\text { Ryburn v. Huff, } 565 \text { U.S. } 469 \\
(2012)\end{array}$ & Local Law Enforcement & $\begin{array}{l}\text { 4th Amdt. } \\
\text { (Search/Seizure) }\end{array}$ & 9th Cir. \\
\hline $\begin{array}{l}\text { Ashcroft v. al-Kidd, } 563 \text { U.S. } \\
731 \text { (2011) }\end{array}$ & U.S. Attorney General & 4th Amdt. (Arrest) & 9th Cir. \\
\hline $\begin{array}{l}\text { Safford Unified Sch. Dist. No. } 1 \\
\text { v. Redding, } 557 \text { U.S. } 364 \text { (2009) }\end{array}$ & School Officials & $\begin{array}{l}\text { 4th Amdt. } \\
\text { (Search/Seizure) }\end{array}$ & 9th Cir. \\
\hline $\begin{array}{l}\text { Pearson v. Callahan, } 555 \text { U.S. } \\
223 \text { (2009) }\end{array}$ & Local Law Enforcement & $\begin{array}{l}\text { 4th Amdt. (Illegal } \\
\text { Entry) }\end{array}$ & 10th Cir. \\
\hline $\begin{array}{l}\text { Brosseau v. Haugen, } 543 \text { U.S. } \\
194 \text { (2004) }\end{array}$ & Local Law Enforcement & $\begin{array}{l}\text { 4th Amdt. (Excessive } \\
\text { Force) }\end{array}$ & 9th Cir. \\
\hline $\begin{array}{l}\text { Groh v. Ramirez, } 540 \text { U.S. } 551 \\
(2004)^{*}\end{array}$ & Federal Law Enforcement & $\begin{array}{l}\text { 4th Amdt. } \\
\text { (Search/Seizure) }\end{array}$ & 9th Cir. \\
\hline $\begin{array}{l}\text { Hope v. Pelzer, } 536 \text { U.S. } 730 \\
(2002)^{*}\end{array}$ & State Corrections Officials & 8th Amdt. & 11th Cir. \\
\hline
\end{tabular}




\begin{tabular}{|l|l|l|l|}
\hline $\begin{array}{l}\text { Saucier v. Katz, 533 U.S. 194 } \\
(2001)\end{array}$ & Military Police & $\begin{array}{l}\text { 4th Amdt. (Excessive } \\
\text { Force) }\end{array}$ & 9 th Cir. \\
\hline $\begin{array}{l}\text { Hanlon v. Berger, 526 U.S. } 808 \\
(1999)\end{array}$ & Local Law Enforcement & 4th Amdt. (Search) & 9th Cir. \\
\hline $\begin{array}{l}\text { Wilson v. Layne, 526 U.S. } 603 \\
(1999)\end{array}$ & $\begin{array}{l}\text { Federal \& State Law } \\
\text { Enforcement }\end{array}$ & 4th Amdt. (Search) & 4th Cir. \\
\hline $\begin{array}{l}\text { Hunter v. Bryant, 502 U.S. } 224 \\
(1991)\end{array}$ & Secret Service & 4th Amdt. (Arrest) & 9 th Cir. \\
\hline $\begin{array}{l}\text { Anderson v. Creighton, 483 U.S. } \\
635(1987)\end{array}$ & Federal Law Enforcement & $\begin{array}{l}\text { 4th Amdt. } \\
\text { (Search/Seizure) }\end{array}$ & 8th Cir. \\
\hline $\begin{array}{l}\text { Malley v. Briggs, 475 U.S. 335 } \\
(1986) * *\end{array}$ & State Law Enforcement & 4th Amdt. (Arrest) & 1 st Cir. \\
\hline $\begin{array}{l}\text { Davis v. Scherer, 468 U.S. 183 } \\
(1984)\end{array}$ & State Law Enforcement & $\begin{array}{l}\text { Due Process } \\
\text { (Employment) }\end{array}$ & 11 th Cir. \\
\hline $\begin{array}{l}\text { Mitchell v. Forsyth, 472 U.S. } \\
511(1985)\end{array}$ & U.S. Attorney General & $\begin{array}{l}\text { 4th Amdt. } \\
\text { (Search/Seizure) }\end{array}$ & 3d Cir. \\
\hline $\begin{array}{l}\text { Harlow v. Fitzgerald, 457 U.S. } \\
800(1982)\end{array}$ & Presidential Aides & $\begin{array}{l}\text { 1st Amdt. } \\
\text { (Employment) }\end{array}$ & D.C. Cir. \\
\hline
\end{tabular}

* Supreme Court found no immunity.

** Court reversed grant of immunity without deciding ultimate immunity question. 